\title{
THE Discovery OF THE SARCOPHAGUS OF DJOSER AND THE RESTORATION OF THE STEP PYRAMID
}

\author{
By
}

\section{Zahi Hawass.}

Former Minister of Antiquities, Cairo, EGYPT

\begin{abstract}
[AR]

اكتشاف تابوت الملك زوسر وترميم الهرم المدرج

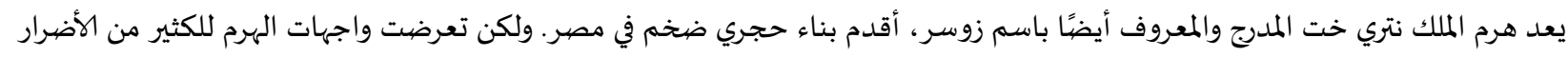

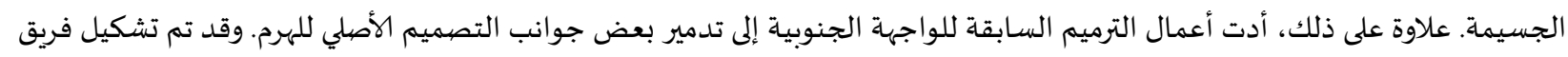

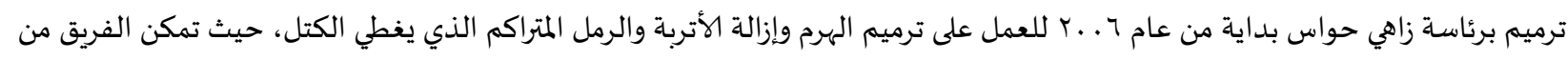

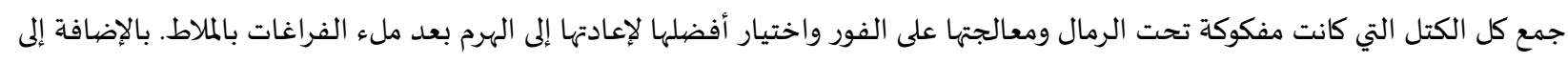

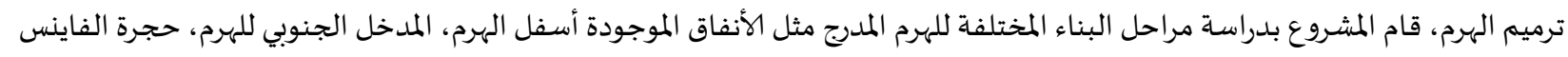

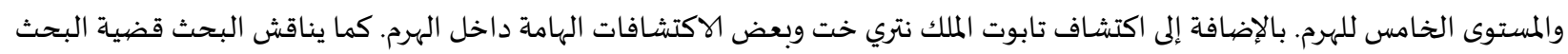

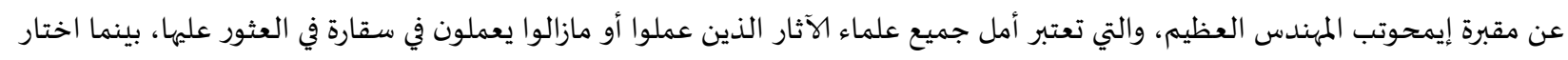

حواس المنطقة الواقعة غرب الهرم المدرج كمنطقة محتملة للبحث عن مقبرة إلمبرة إيمحوتب.
\end{abstract}

[EN] The Step Pyramid of Netjerikhet (also known as Djoser) is the oldest monumental stone structure in Egypt. Much of the pyramid's façade has suffered significant damage. Moreover, previous restoration work on the south façade destroyed some of the pyramid's original design. The restoration team Led by Zahi Hawass has worked since 2006 to remove the accumulated dust and sand that covered the blocks. The team was able to collected the loose blocks from under the sand, treat them immediately, and chose the best place for them in within the pyramid after filling the gaps with mortar. In addition to the restoration of the pyramid, the project studied and confirmed the different construction phases of the Step Pyramid such as the tunnels under the pyramid, the south entrance of the pyramid, the room of the faience tiles and the wall stela, and the fifth level of the pyramid. In addition, the team discovered the sarcophagus of Netjerikhet and made some other important discoveries inside the pyramid. The paper will also discuss the issue of the search for the discovery of the tomb of Imhotep, such a discovery is the hope of all archaeologists who have worked or are working at Saqqara. Indeed, Hawass chose the area west of the Step Pyramid as a likely area to search for the tomb of Imhotep.

KEYWORDS: Step Pyramid, Djoser, Netjerikhet, Façade, Restoration, Imhotep, Faience. 


\section{I.INTRODUCTION}

The Step Pyramid of Netjerikhet (also known as Djoser) is the oldest monumental stone structure in Egypt. Much of the pyramid's façade has suffered significant damage. On the north façade, we could see accumulation of dust and wind-blown sand, as well as, loose and falling block fragments [FIGURE 1]. We could also see the same patterns of damage clearly on the northeastern and northwestern corners of the pyramid, along with the western façade [FIGURE 2]. Moreover, previous restoration works on the south façade destroyed some of the pyramid's original design [FIGURE 3].

Evidence of destruction includes:

1. Loose blocks.

2. Falling block fragments.

3. Accumulation of dust and wind-blown sand.

4. Holes and gaps.

5. Fallen mortar.

6. Additional signs of destruction outside as well as inside the burial chamber.

In 2003, we contacted the Center of Engineering (Archaeology Faculty of Engineering, Cairo University) and they recommended Dr. Hassan Fahmy Emam to be the consultant for the project to restore and conserve of the Step Pyramid. After Dr. Fahmy conducted a detailed study of the condition of the pyramid, he proposed a very impressive project to save it. We held many meetings to analyze and discuss his study and were convinced of the importance and potential of the project.

In 2006, we issued a request for tender to a number of construction companies. The winning tender was made by the Shabraweshi Construction Company, which was chosen to do the work under Dr. Fahmy's supervision. I also appointed a committee of Egyptologists, architects, and restorers to supervise the restoration. The project came to a temporary halt in 2011 due to the unstable political situation in Egypt at the time, and was resumed again in 2013. The project was victim to a great deal of misinformation and rumor spreading by ignorant people during that period. Such rumors had no scientific basis. Fortunately, the project was completed in 2019 and was officially inaugurated by Dr. Mostafa Madbouly, the Prime Minister of Egypt, and Dr. Khaled El Enany, Minister of Tourism and Antiquities.

- The team who worked on the project of the Step Pyramid Restoration Project included: DR. HASSAN FAHMY EMAM: Consultant for the project, who supervised every stage of the restoration work; ENG/ MicheL GABRIEL: El Shorbagy Company Representative from the Supreme Council of Antiquities:

- Archeologists: Afifi Roheim, SAbri Farag, Mohamed Shabah, SAmHan Mohamed Abdel Salam, SAMIER ABDELRAFOUF \& MOSTAFA HASSAN.

- Restorers: SABRI ABDEl GHAFAR, MOSTAFA AHMED \& ASHRAF FAHMY.

- Architects: KAMEl LOUIS, HAMDY RASHWAN \& MAHMOUd MASOUF. 


\section{BRIEF DESCRIPTION OF THE RESTORATION}

The restoration team worked on removing the accumulated dust and sand that covered the blocks. The fallen blocks were buried under a great deal of sand and debris that needed to be moved so that the blocks could be restored. The thick layers of accumulated debris and sand were heavy, creating pressure on the interior structure of the pyramid. These layers contained a lot of salt that was causing the blocks to deteriorate and crack.

The team was able to collect all blocks that were loose under the sand, treated them immediately, and chose the best of them to be placed back onto the pyramid after filling the gaps with mortar. The mortar that was used consisted of the same ratio of limestone to sand used by the ancient Egyptians to construct the original pyramid. On the east façade of the pyramid, part of the original outer casing of Tura limestone remained. This casing was angled so that rainwater would run off. The holes and gaps in all four façades were cleaned and refilled.

In addition to the restoration of the pyramid, the project studied and confirmed the different construction phases of the Step Pyramid, as follows:

a) An initial small mastaba, the outlines of which is currently visible from the south side.

b) A second mastaba was then built in a second phase. It was wider than the first one, in the middle of which, the burial chamber and the burial shaft were cut.

c) The last stage was finishing the construction of the step pyramid to the shape that we see today.

\section{The TunNels UNDER THE PyRAMID}

The restoration team cleaned the tunnels that are located on the five levels in the substructure of the Step Pyramid, all of which had also suffered much destruction. On the fifth level, tunnels were cut into the limestone bedrock beneath the pyramid at a width of 1 meter and a depth of 5 meters. In many places, the solid rock was cracked and other tunnels were filled with debris from fallen rocks and blocks. The walls of faience tiles and Djoser's carved reliefs had suffered damage, as had artifacts such as the Egyptian alabaster (travertine) sarcophagus found in the tunnels. The team removed the remains of stones and dust, secured and restored the tunnels through major consolidation to the walls of the tunnels ${ }^{1}$.

\section{The South ENTRANCE OF THE PYRAMid}

The south entrance in the superstructure was dug during the Saite Period (Dynasty 26). It is about 50.50 meters long, running south to north, and the width varies from 3 meters to 3.45 meters. It is 1.75 meters to 1.85 meters in height. The ceiling of this entrance was held up by a row of twenty small stone pillars. Some are square and some are circular, and all are stylistically similar to pillars dated to the New Kingdom. They may have been moved from a New Kingdom building at Saqqara during the Saite Period. Dynasty 26 is known for its veneration of earlier

1 VERNER 1997: 68 - 101. 
periods, and Saite engineers built this entrance tunnel in order to remove debris from the original main shaft so that they could re-discover and restore the royal

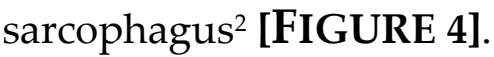

Additionally, we can see a natural crack in the ceiling of this tunnel, running from north to south and ending at the entrance. This was the reason for the installation of the pillars, to protect and support this tunnel. They also installed wooden beams to protect the workmen who cleared burial shaft. We can see these wooden beams on the upper part of the ceiling of the shaft. On the walls of this tunnel, there are open niches with the residue from burning on the sides; these may have been used for lamps to light the tunnel [FIGURE 5].

\section{THE ROOM OF THE FAIENCE TILES AND THE WALl STELA}

From the southeast corner of the sarcophagus chamber at the bottom of the burial shaft, there is a short tunnel leading to two rooms decorated with blue faience tiles. On the lintels of the entrances to these two rooms, we found the inscribed titles of Netjerikhet. The walls of the two rooms were cased with fine white limestone, with rows of blue faience tiles set into the walls. Each row is separated by horizontal bands of limestone carved to resemble linen ropes. This decoration is designed to mimic reed mats that would have covered the walls of actual buildings.

In this area, there is also some hieroglyphic graffiti that has been left on the stone blocks by the ancient workers. Moreover, paintings of stars painted in black ink can be found on the ceiling of the entrance that led to the room. On the south side of the faience room are three stelae that contained the names and titles of Netjerikhet, where he is also shown wearing the White Crown of Upper Egypt. The stelae are surrounded by rows of bluish-green faience tiles ${ }^{3}$. These rooms, as well as the wall stelae of Netjerikhet, were completely documented and restored [FIGURES 5-7].

\section{THE FIfTH LEVEL OF THE PYRAMID}

We reached the fifth level of the interior of the Step Pyramid through two entrances. The first entrance is a very small opening that is about one meter wide and five meters deep, located in the middle of the passage that contains the wall stelae of Netjerikhet.

The second entrance to the fifth level is on the east side of the pyramid where a slope down in the bedrock leads to one of the eastern royal shafts. This entrance includes a series of passages and tunnels connected to each other, running both from north to south and from east to west. One of these tunnels runs from west to east and ends at a vertical shaft leading to the top, at the eastern part of the structure of the first mastaba. The walls of the fifth level are fragile and have been severely damaged because of the high level of humidity. All the tunnels and walls were documents, restored, and consolidated ${ }^{4}$ [FIGURE 8].

\footnotetext{
2 VERNER 1997: 78-79.

3 VERNER 1997: 80-81.

4 VERNER 1997: 79-82.
} 
We can also see from the interior of the tunnels, on the fifth level, the shafts that be longed to the royal family. However, the shafts are full of dust and debris accumulation, including huge stone blocks that required thorough engineering and archaeological studies before they can be restored. Also, on the fifth level is a large room with limestone walls that required immediate restoration. I believe that the fifth level still needs more restoration in order to secure the tunnels. It is also possible that the interior of the Step Pyramid could contain a sixth level. We will be able to see this clearly after we open the outer shaft for ventilation and use it to remove the debris on the fifth level.

\section{IMHOTEP: WHERE IS HIS TOMB?}

The discovery of the tomb of Imhotep is the hope of all archaeologists who have worked or are working at Saqqara. Walter Emery spent his life searching for the tomb inNorth Saqqara. As Miroslav Verner has explained, the reason that Emery chose the north part of Saqqara was because Imhotep was worshipped in the Late Period as the deity Asklepios in the area around the Serapeum ${ }^{5}$.

Walter Emery never found the tomb; he died and was buried in Cairo before he could make his dream come true. More recently, Ian Mathieson began to work on the area west of Gisr el Mudir and discovered a large limestone wall that he thought might lead to something important, but he found nothing. He also used satellite imaging on the area north of the pyramid of Userkaf, where he thought that the tomb of Imhotep might be, but again there was no evidence of this tomb.

In 2010, I chose the area west of the Step Pyramid as a likely area to search for the tomb of Imhotep. Our excavation began about 60 meters away from the west side of the pyramid, within the enclosure wall of the pyramid complex. In this area we found a shaft connected with a tunnel, inside which we found artifacts dating to the $2^{\text {nd }}$ Dynasty.

I wonder now whether Imhotep might have been buried under the Step Pyramid. The reasons for this theory are based on Senenmut, the architect of Queen Hatshepsut of Dynasty 18. Senenmut took Imhotep as his role model and referred to him in a chapelinside Hatshepsut's temple at Deir el Bahari. Since Senenmut chose to be buried under the Deir el Bahari temple, I believe he did so in imitation of his role model Imhotep. Also, we know that the only pyramid in the Old Kingdom under which queens were buried is the Step Pyramid of Netjerikhet.

The idea for this came from the architect affiliated with El-Shorbagy, who worked on the restoration of the pyramid. One day, when I was with a group of people at the end of the Saite corridor south of the pyramid, an architect mentioned that he had found a big gap below the end of the entrance on the north side of the shaft, but he was not able to further investigate. He suggested that this might lead to the burial area of Imhotep. It is a compelling idea, and I hope that we can explore this further in the future.

5 GAMAL EL-Din \& FAHMY 2007: (Unpublished report). 


\section{THE DISCOVERY OF THE SARCOPHAGUS OF NETJERIKHET}

The main shaft inside the Step Pyramid was one of the major problems that we faced during the restoration project. We discovered that the burial chamber had never been excavated before, and the sarcophagus had never been found. The shaft contained a great deal of debris, including a great deal of stone rubble. Some of this debris came from the ceiling of the chamber itself. The situation was made worse by the earthquake of 1992. The shaft is square, measuring about 7 meters by 7 meters; its depth is about 28 meters. We removed more than 400,000 square meters of stones and rubble from this shaft to clear it.

We carefully examined the debris for any artifacts and saved the stones that could be used for the conservation of the shaft. We began to support the collapsing stone pillars and the walls of the burial chamber with supporting blocks. The mortar that was used for the restoration consisted of lime and sand in the same proportions as those used by the ancient Egyptians. All the entrances to the tunnels were also restored. The discovery of a granite sarcophagus, broken into 32 pieces, was a huge surprise. Its dimensions are 3.47 meters x 5.35 meters and it is 4.73 meters in height; weighing about 1.76 tons [FIGURE 9].

We also found an open area at the top lid of the sarcophagus, which contained a cylindrical stopper made of granite. This piece is about 3 tons in weight and was restored to its original location. The team discovered that the sarcophagus was resting on 18 blocks of limestone for support. All these blocks had been destroyed under the heavy debris that filled the chamber.

The limestone supports were consolidated along with the entire area underneath the sarcophagus. In the shaft, the team also found a number of blocks of Egyptian alabaster and limestone carved with stars. Some blocks had stars on one surface, while others hadstars on both sides. This suggests that there was a calcite (travertine) ceiling decorated with stars in a burial chamber above the level of the one where the sarcophagus currently lies. That chamber had its walls cased in calcite (travertine). This is further supported by the higher level of the northern entrance into the pyramid compared to the level of the sarcophagus. This also suggests that it might have led to a room above the current burial chamber, which was destroyed when the ceiling collapsed [FIGURE 8].

Openings present on the eastern and western sides of the shaft might have been used to install wooden beams to help raise the granite stopper of the sarcophagus using ropes after the burial of the king in the $3^{\text {rd }}$ Dynasty. There are hieroglyphs on the graniteblocks of the sarcophagus, which indicate the directions north and south in order to guide the workmen who placed the sarcophagus in the chamber.

On the western corner of the shaft from the top, there is a tunnel or a serdab heading north. It runs for about 53 meters in length, with 1.20 meters in width, and a height of approximately 90 centimeters. Its end is blocked with stones but could have possibly led to the mortuary temple north of the pyramid. This tunnel was probably dug by tomb robbers, who were able to reach the burial chamber from the top through a vertical tunnel on the side of the shaft, leading directly to the burial chamber.

\section{[FIGURE 11]}


There are many tunnels and vestibules on the fourth level near the burial chamber, perhaps used for storage funerary equipment. All are open and connected; they lead in the end to the burial chamber. All the blocks or fragments that contain painted stars were collected for study.

On the northern side of the shaft is the main entrance to the burial chamber. It is cut into the bedrock and would have been blocked with stones after the burial of the king. The entrance located in the middle of the chamber is situated to face the sarcophagus. This area was restored and consolidated because it was too dangerous to leave it as we found it. Above this entrance are two stone lintels. This entrance originally led north to the outside of the pyramid, to the mortuary temple, and was closed during the third stageof the pyramid construction [FIGURE 12].

\section{DISCOVERIES INSIDE THE PYRAMID}

The team found remains of three Late Period mummies, covered in painted cartonnage, inside the burial chamber during the removal of debris. They also found, a piece of limestone inscribed with the names of Netjerikhet and two princesses, one is the szt nswt Int-kawes, and the second is Hetep-her-nebty.

$\check{s} 3 t n s w t$ - daughter of the king $\check{s} 3 t$ nst inkts and st nswt ḥtp-ḥr nbty [FIGURE 13].

The team also found wooden tools such as mallets, faience chunks, and many types of pottery shreds, in addition to square and rectangular stone fragments decorated with stars, as mentioned above [FIGURE 14].

Among the finds was a faience head of Horus, a bronze statue of Osiris, about $64 \mathrm{~cm}$ high (found in area of the western façade of the first-stage mastaba; a cylindrical vessel made of calcite (found inside the funerary temple). In addition, there was a great deal of ancient graffiti on the outside of the pyramid [FIGURES 15 - 19]. 


\section{BIBLIOGRAPHY}

Gamal EL-Din, A. \& FAHMY, H.: The Archaeological and Conservation Report of the Step Pyramid RestorationProject, (unpublished report) 2007.

VERnER, M.: The Pyramids: The Archaeology and History, Cairo (American University in Cairo Press), 2007.

IAN MATHIESON \& JON DitTMER: «The Geophysical Survey of North Saqqara, 2001-7», The Journal of Egyptian Archaeology 93, 2007, 79-93.

HAWASS, Z.: «Excavations West of the Pyramid of Netjerikhet» forthcoming; Excavations Stopped as aResult of the Political Instability in Egypt during 2011. 


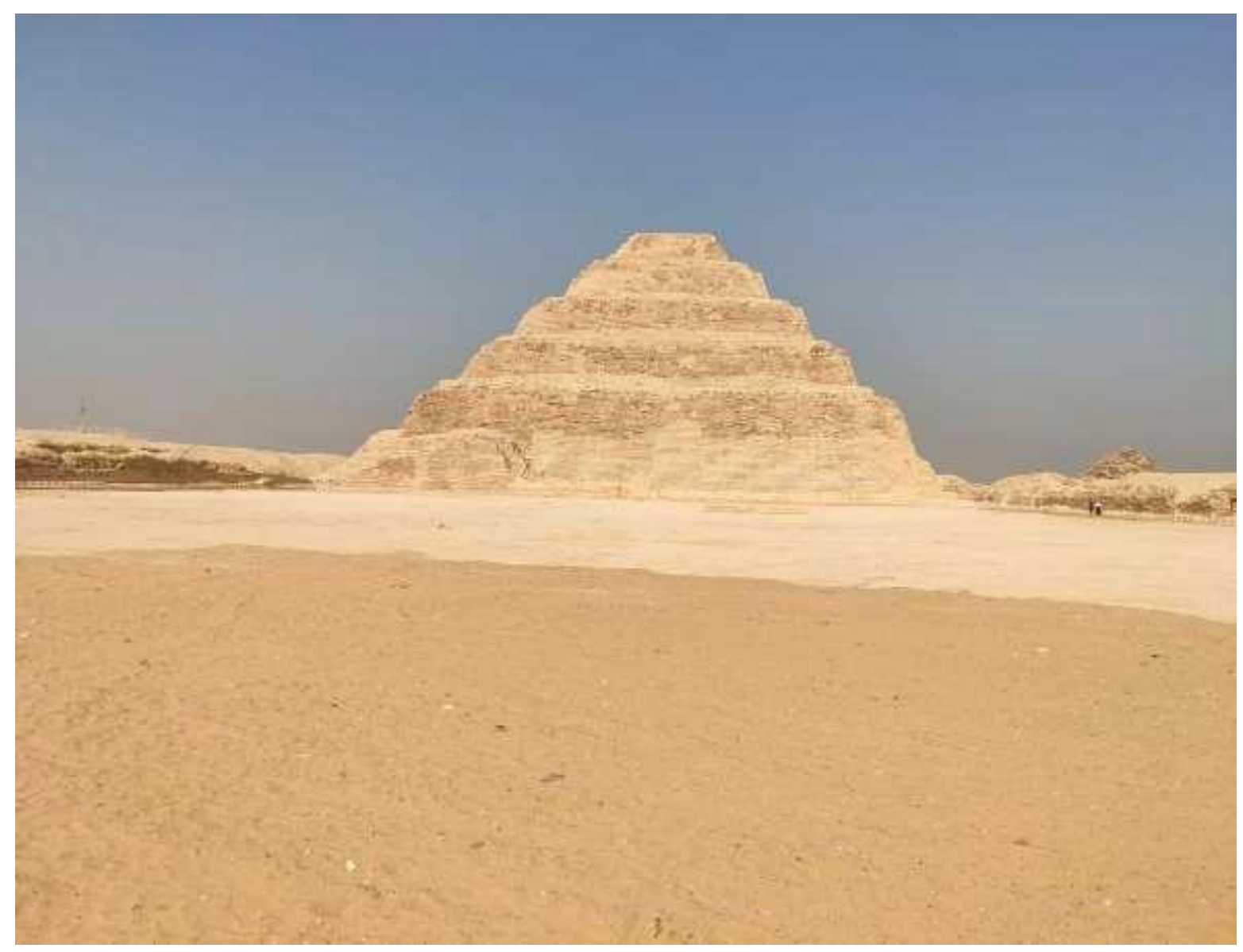

[FIGURE 1]: North façade @ credit by HAWASs 2006.

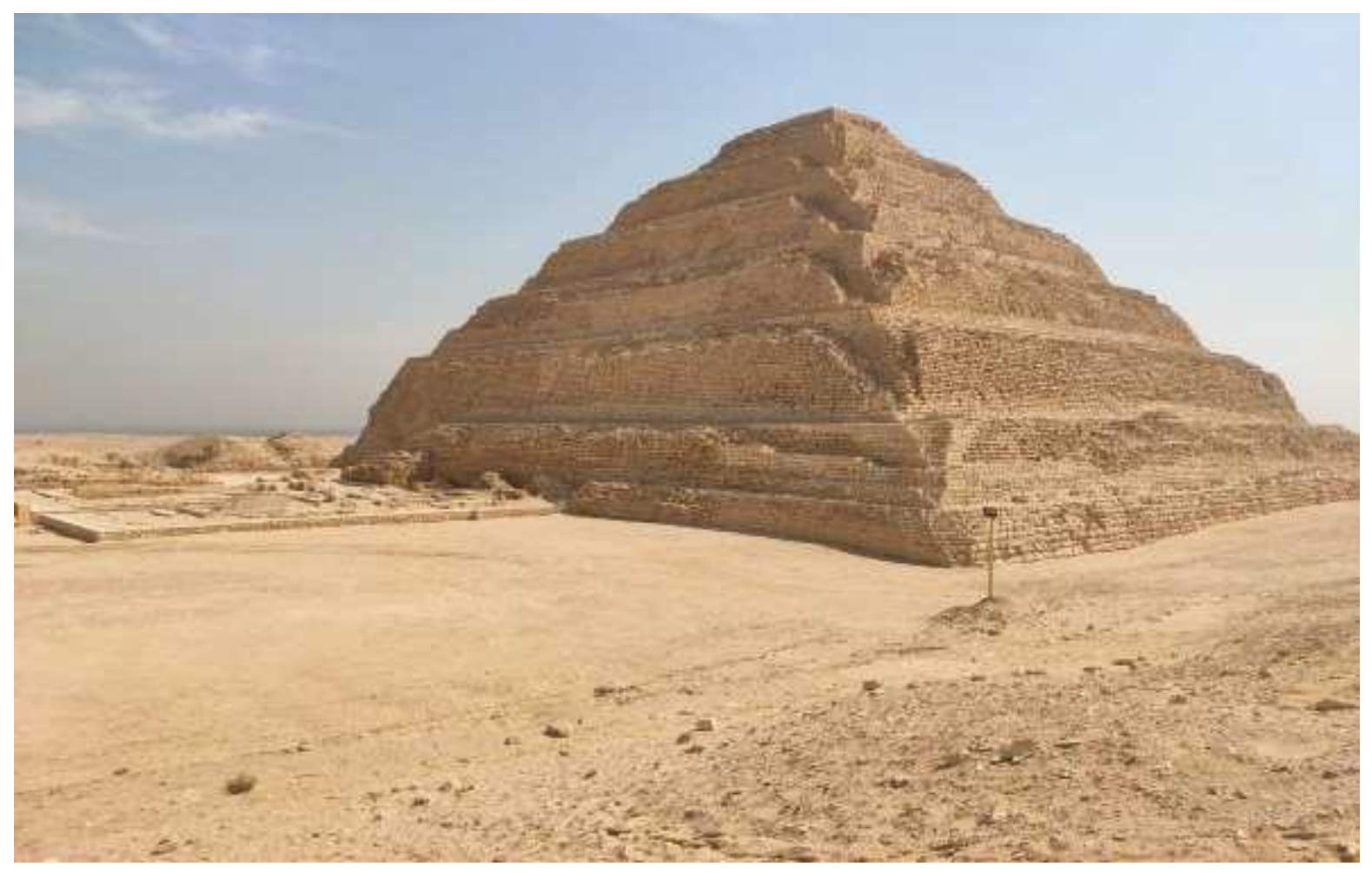

[FIGURE 2]: West façade Ccredit by HAWASs 2006. 


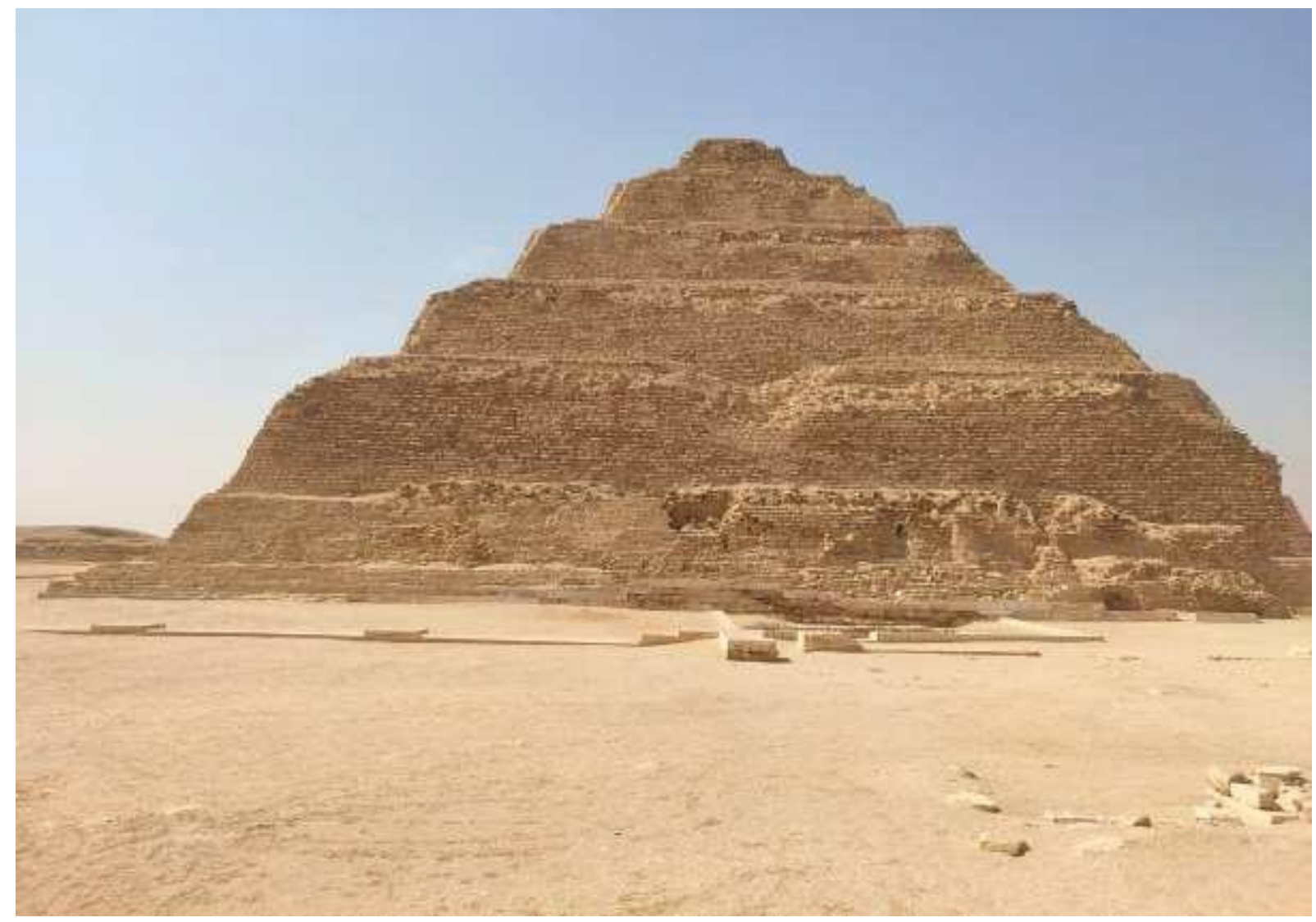

[FIGURE 3]: South façade @credit by HAWASs 2006.

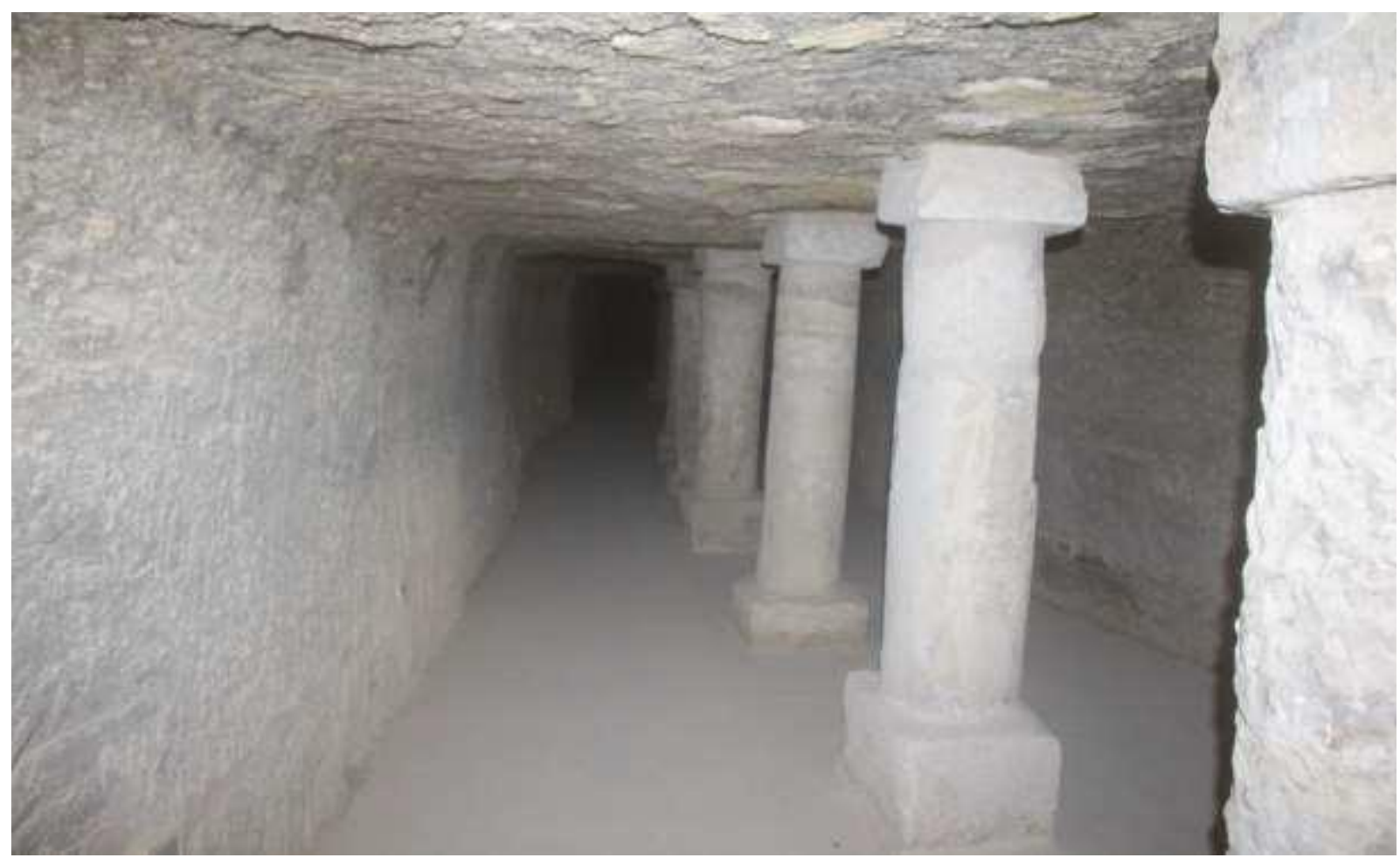

[FIGURE 4]: inside the South entrance @credit by HAWASS 2018 


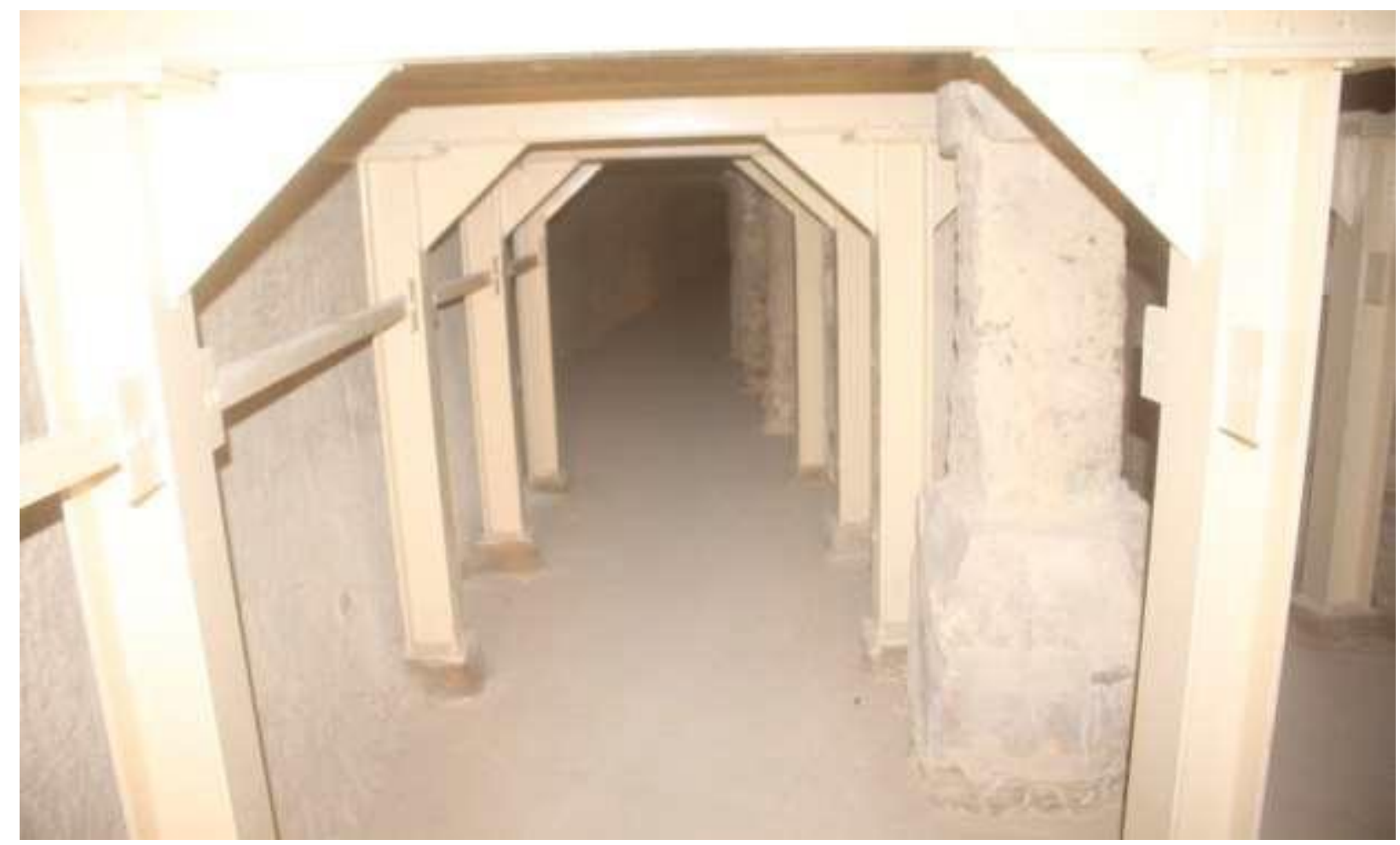

[FIGURE 5]: Restoration of the South entrance $\odot$ credit by HAWASS 2018.

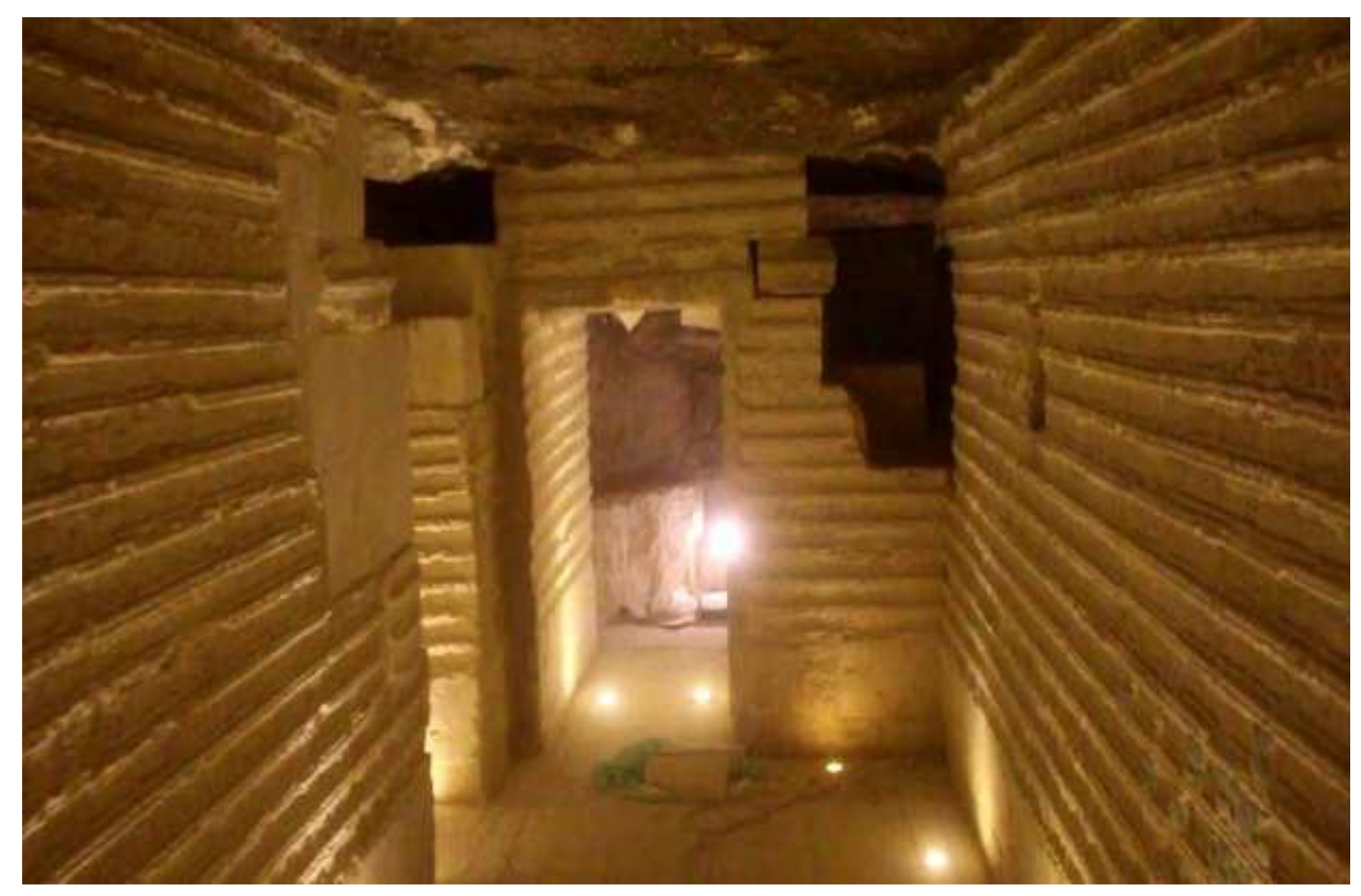

[FIGURE 6]: Room of the faience Tiles @ credit by HAWASs 2018. 


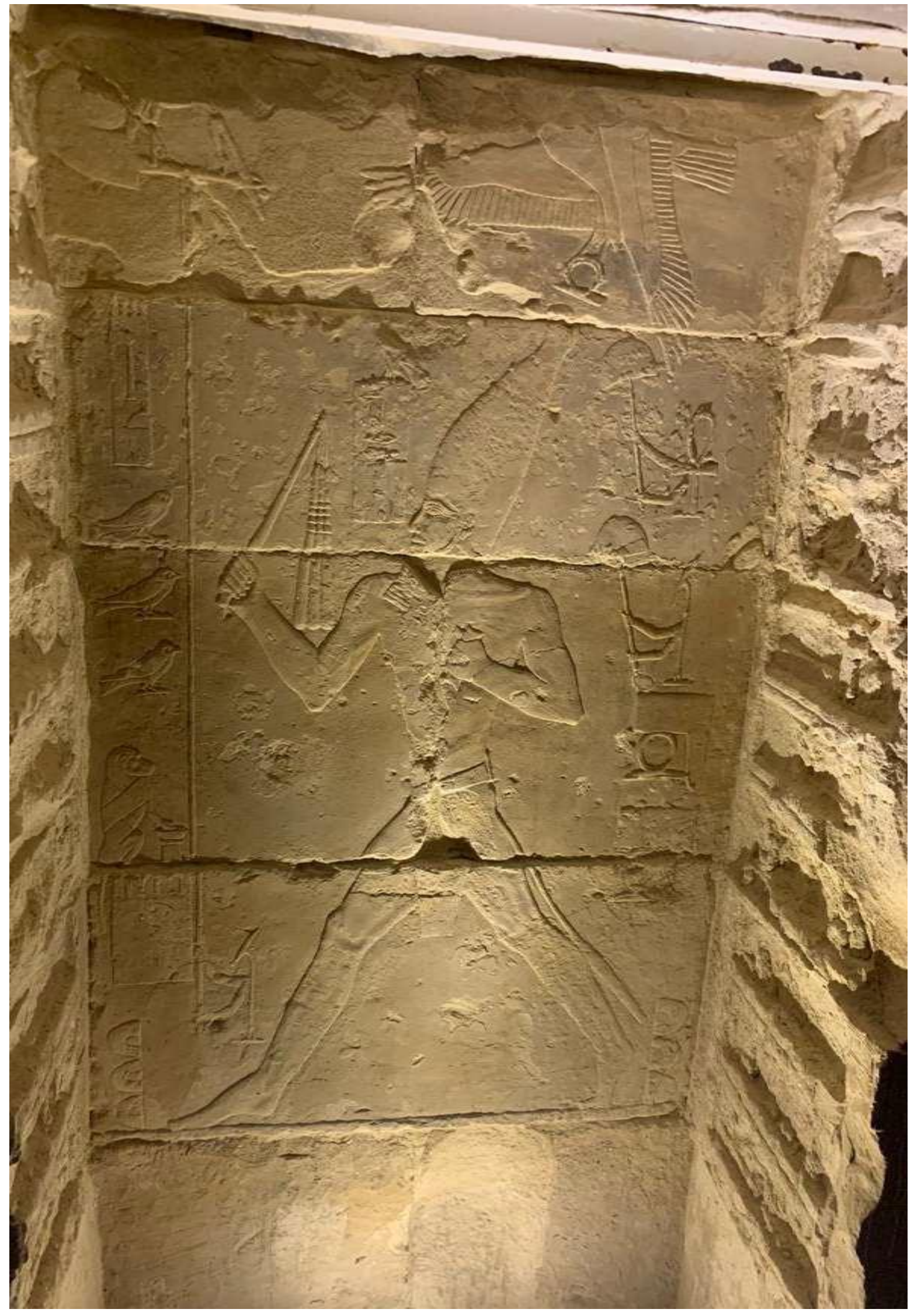

[FIGURE 7]: The Wall Stela @ credit by HAWASS 2018. 


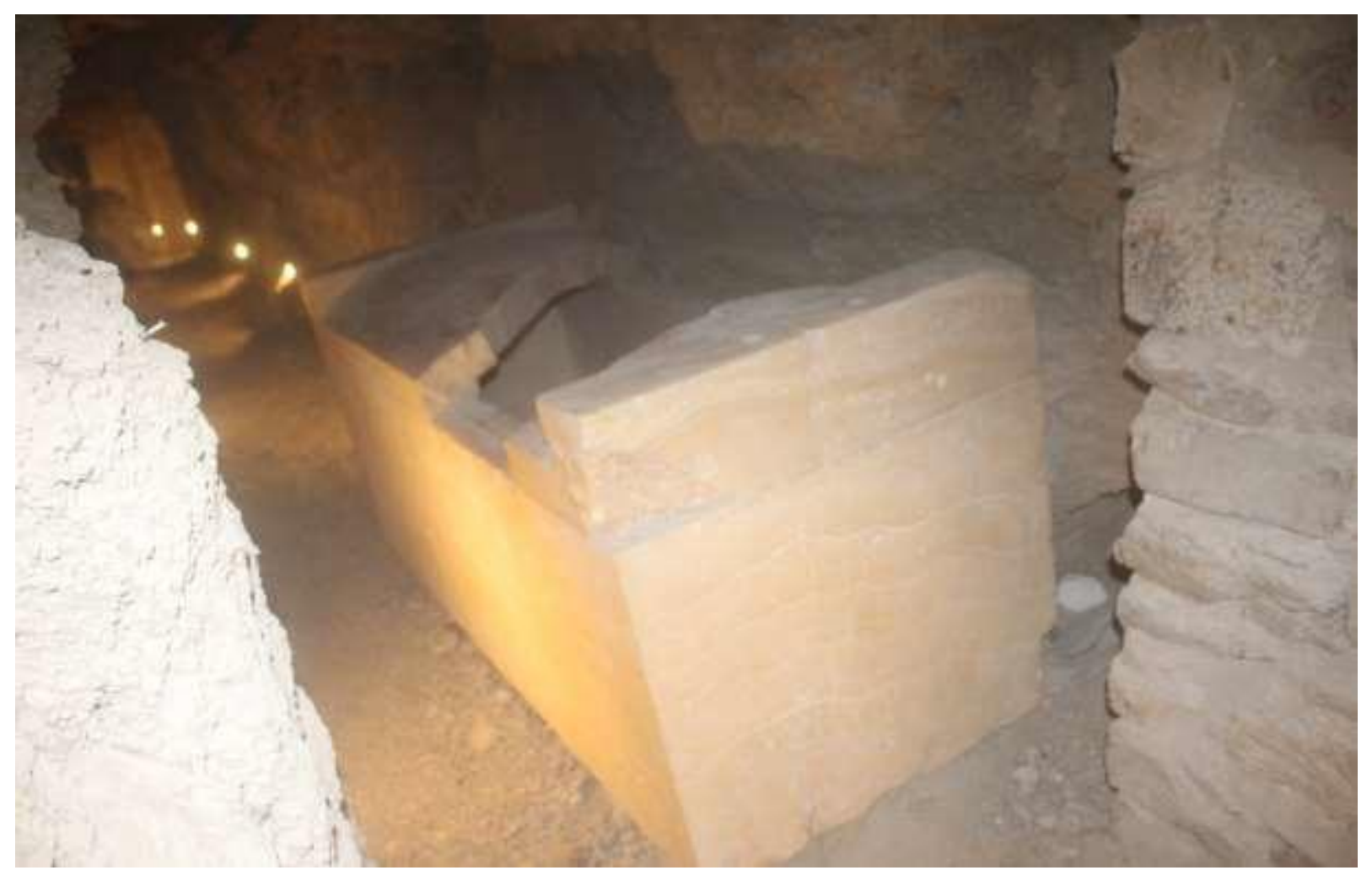

[FIGURE 8]: The Alabaster Sarcophagus on the fifth level $\odot$ credit by HAWASs 2018.

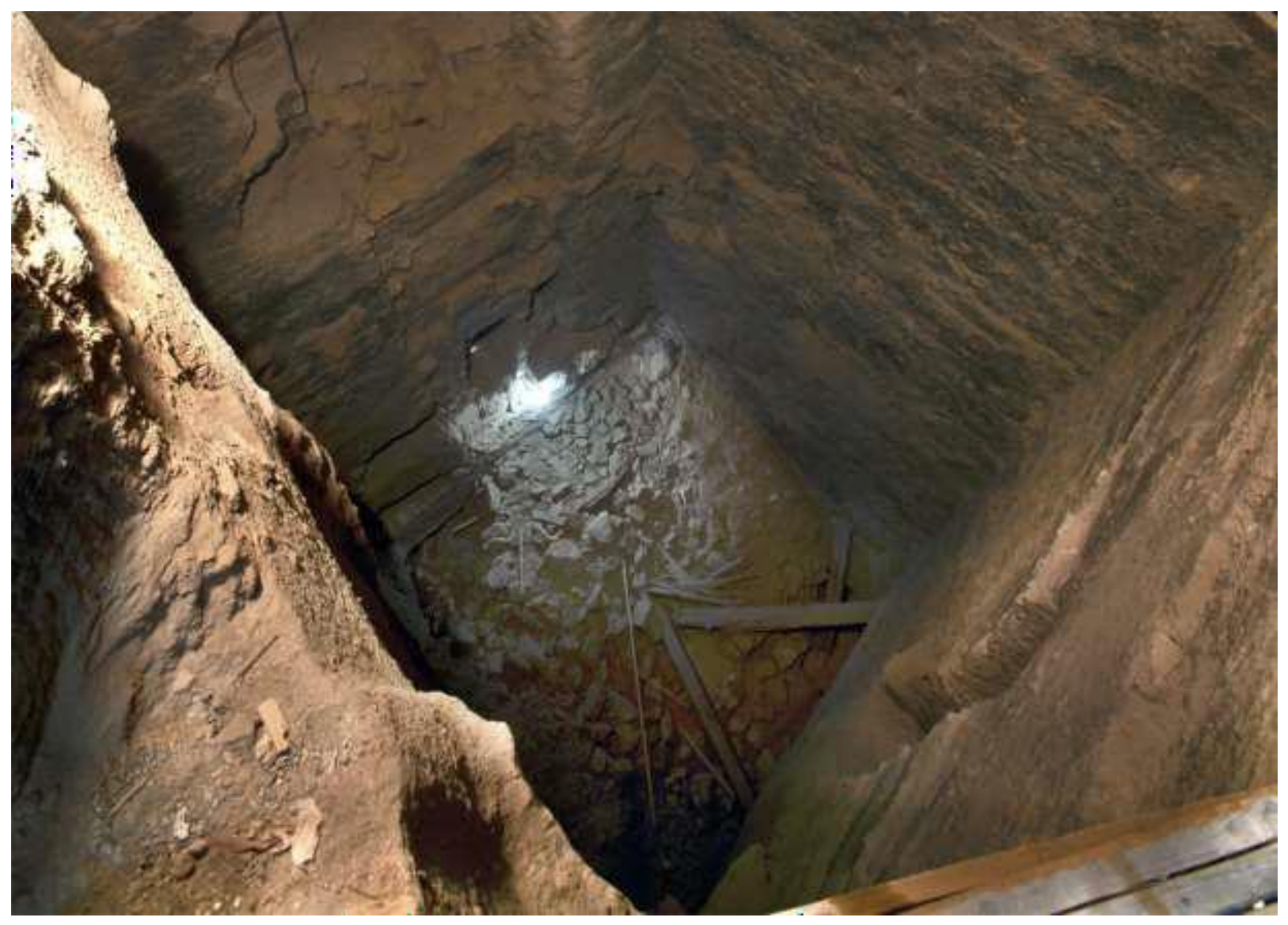

[FIGURE 9]: The Burial chamber before the removal of the sand and stones $\odot$ credit by HAWASS 2018. 


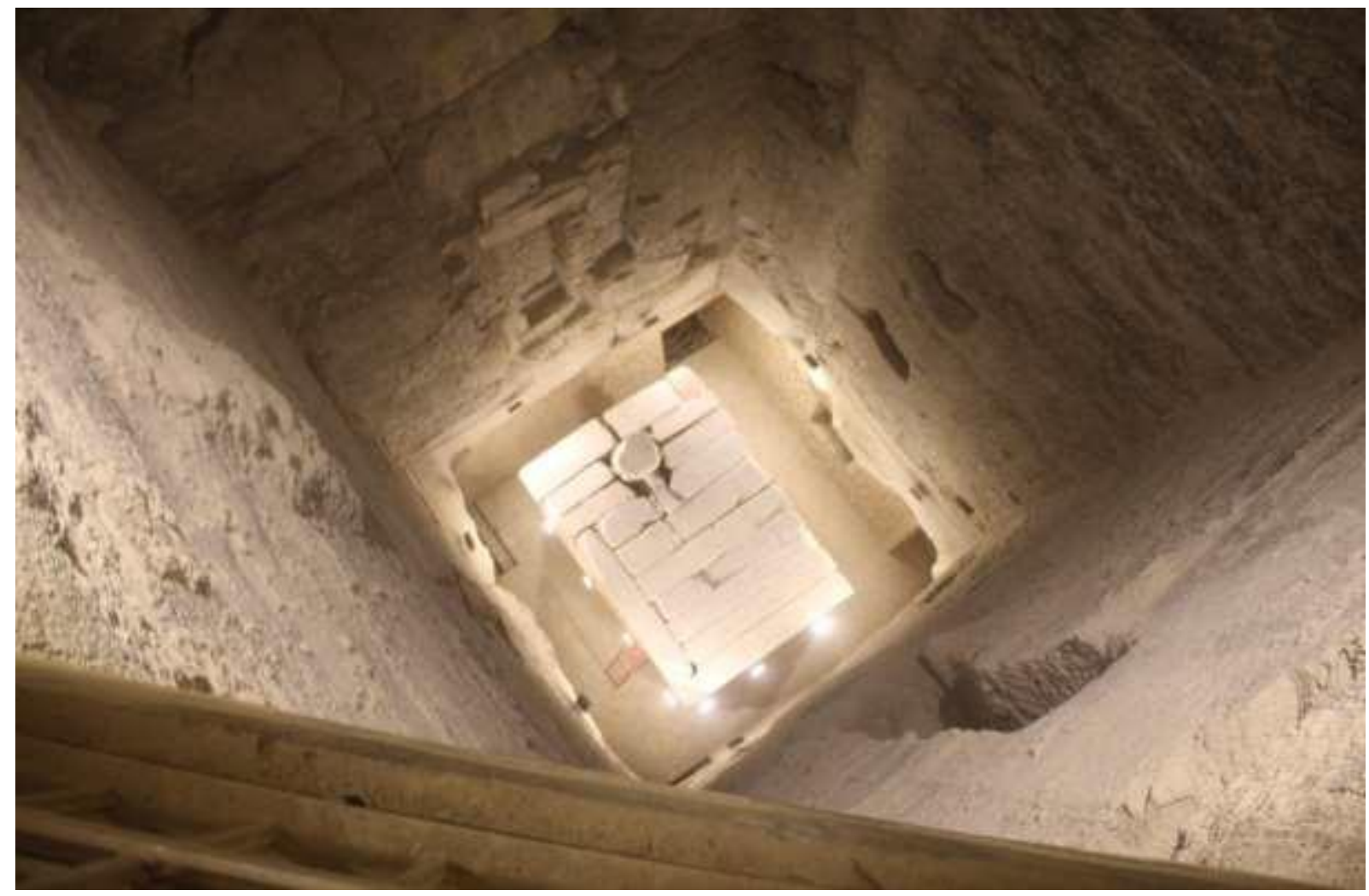

[FIGURE 10]: The Sarcophagus in the Burial chamber @ credit by HAWASs 2018.

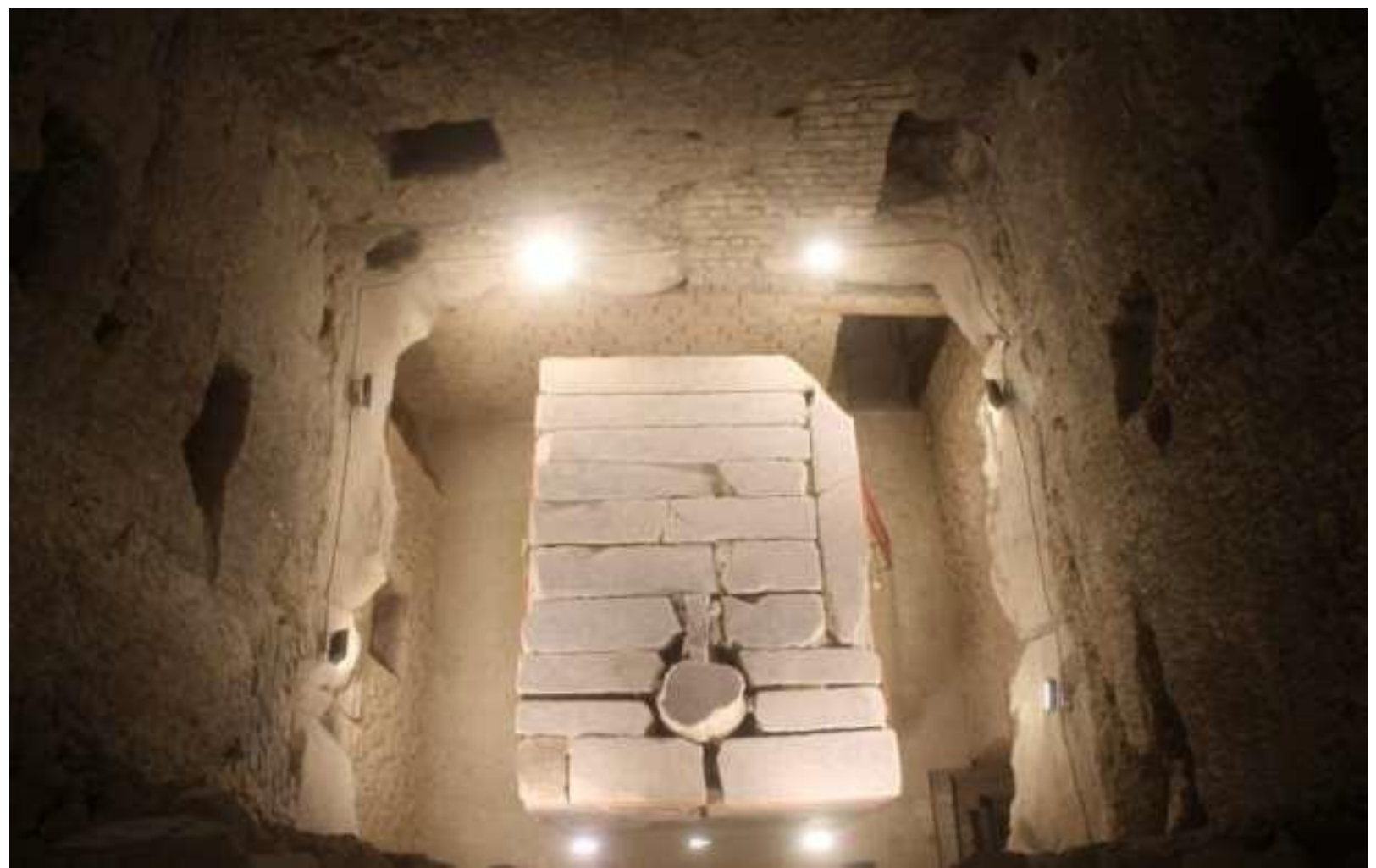

[FIGURE 11]: The Sarcophagus @credit by HAWASs 2018. 


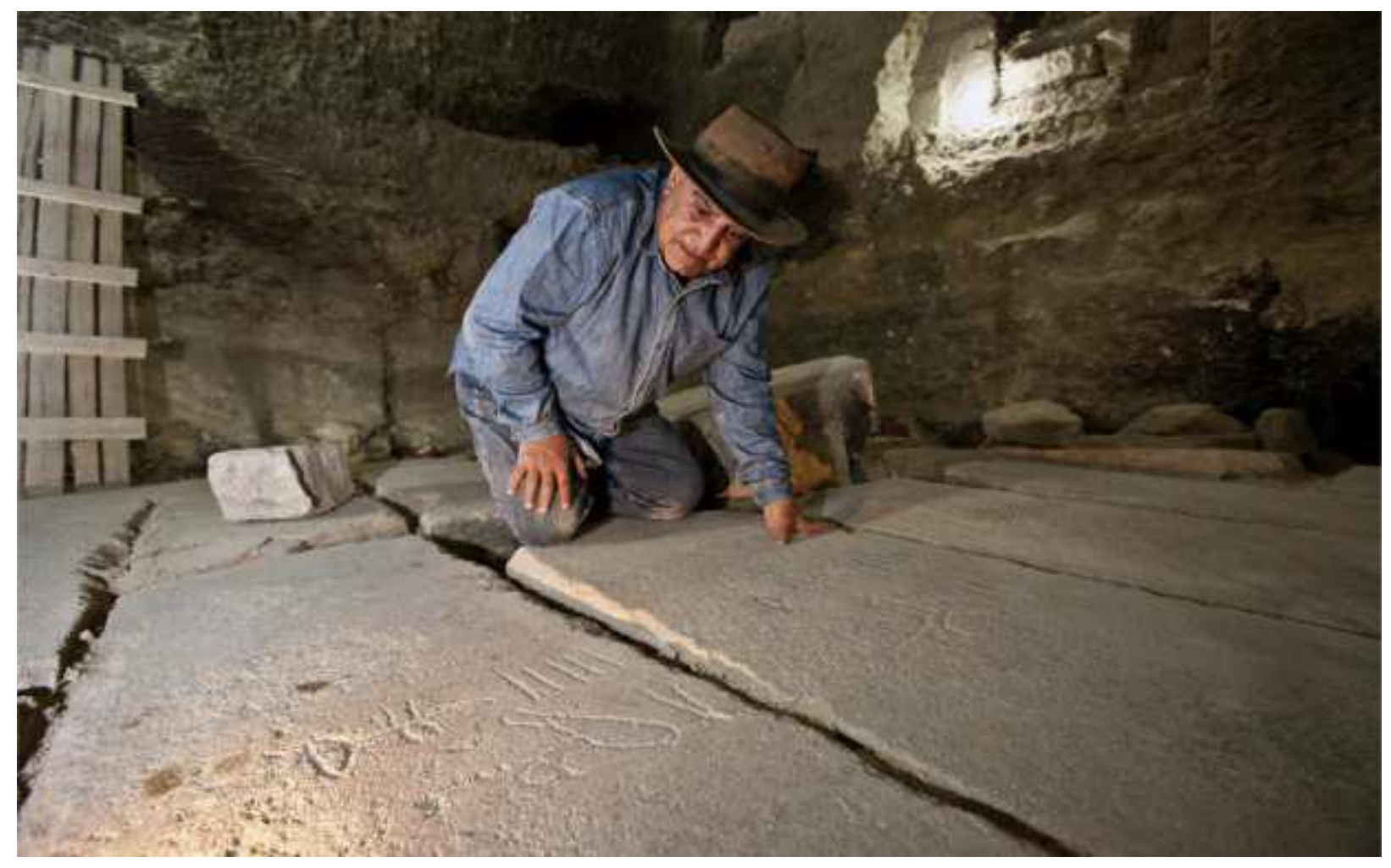

[FIGURE 12]: The Sarcophagus and the Graffiti in Hieroglyphic North and South signs. Ccredit by HAWASS 2018.

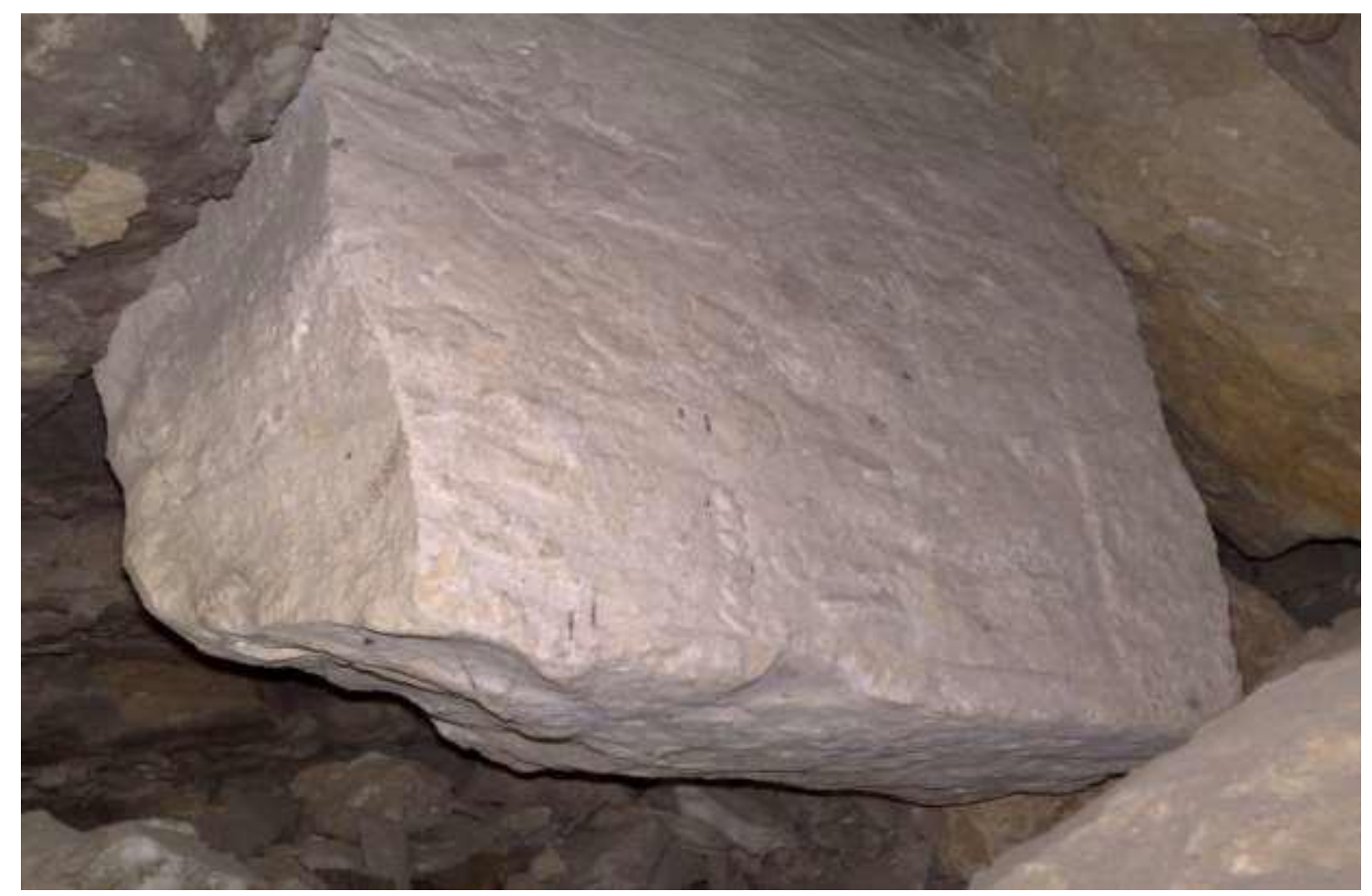

[FIGURE 13]: Stone on it the names of Djoser's daughter @ credit by HAWASs 2018 


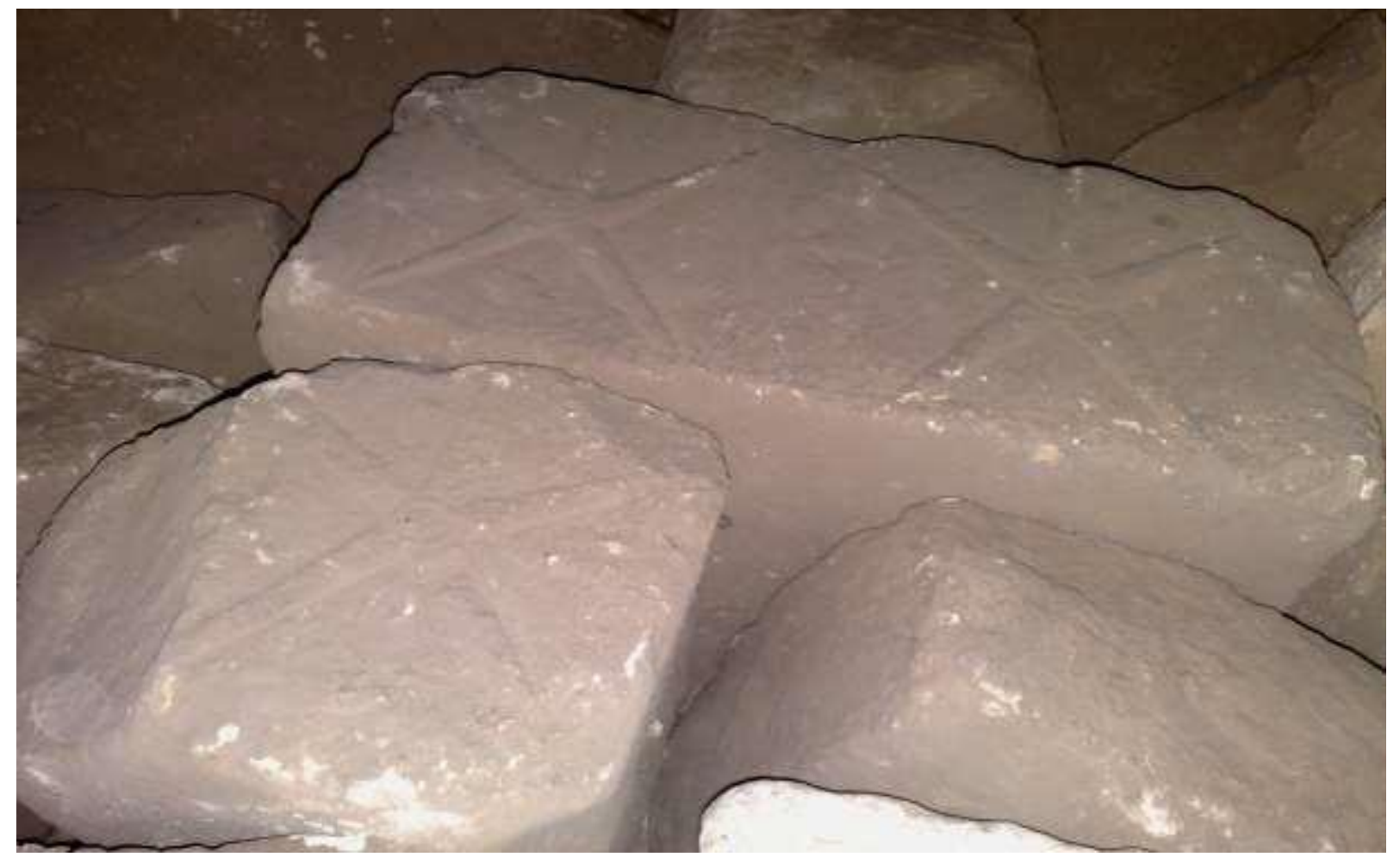

[FIGURE 14]: Stars on the Stones @ credit by HAWASS 2018.

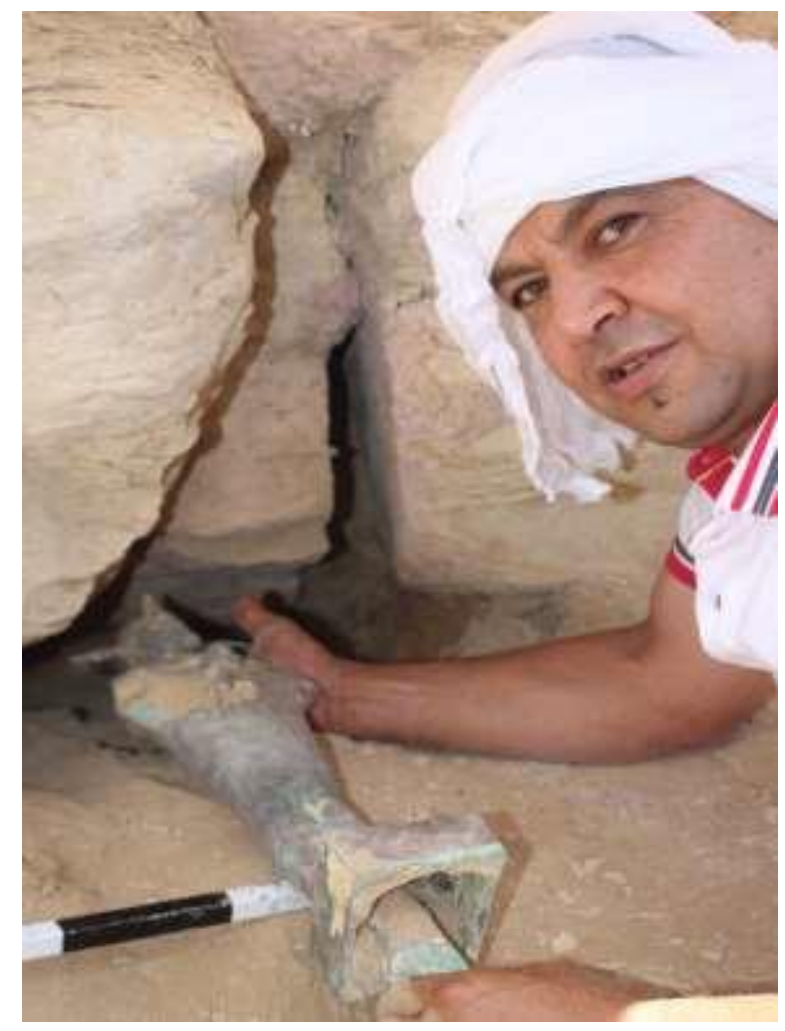

[FIGURE 15/A]: statue of Osiris and alabaster vessel found in the funerary temple. (c) credit by HAWASS 2020. 


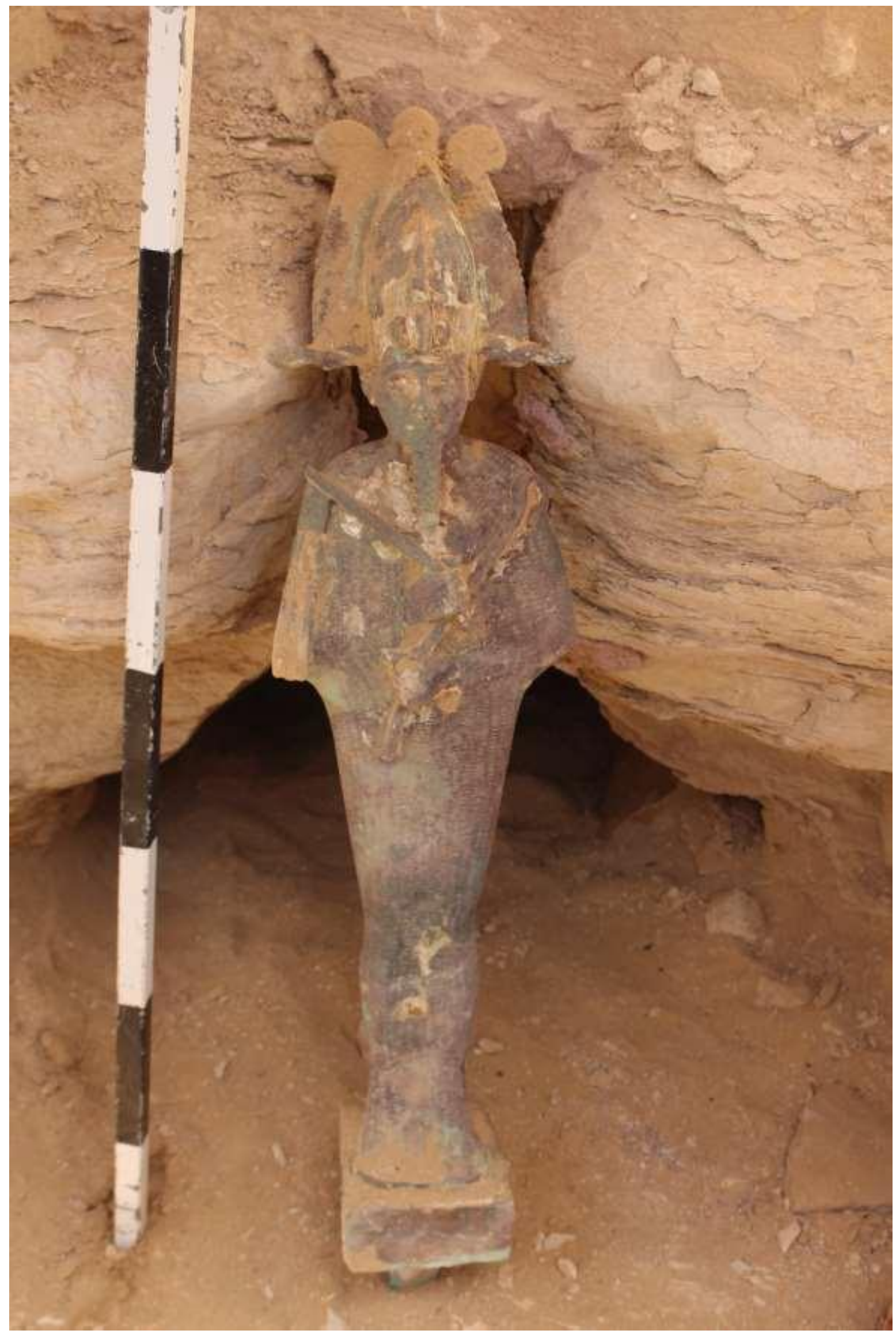

[FIGURE 15/B]: Statue of Osiris 


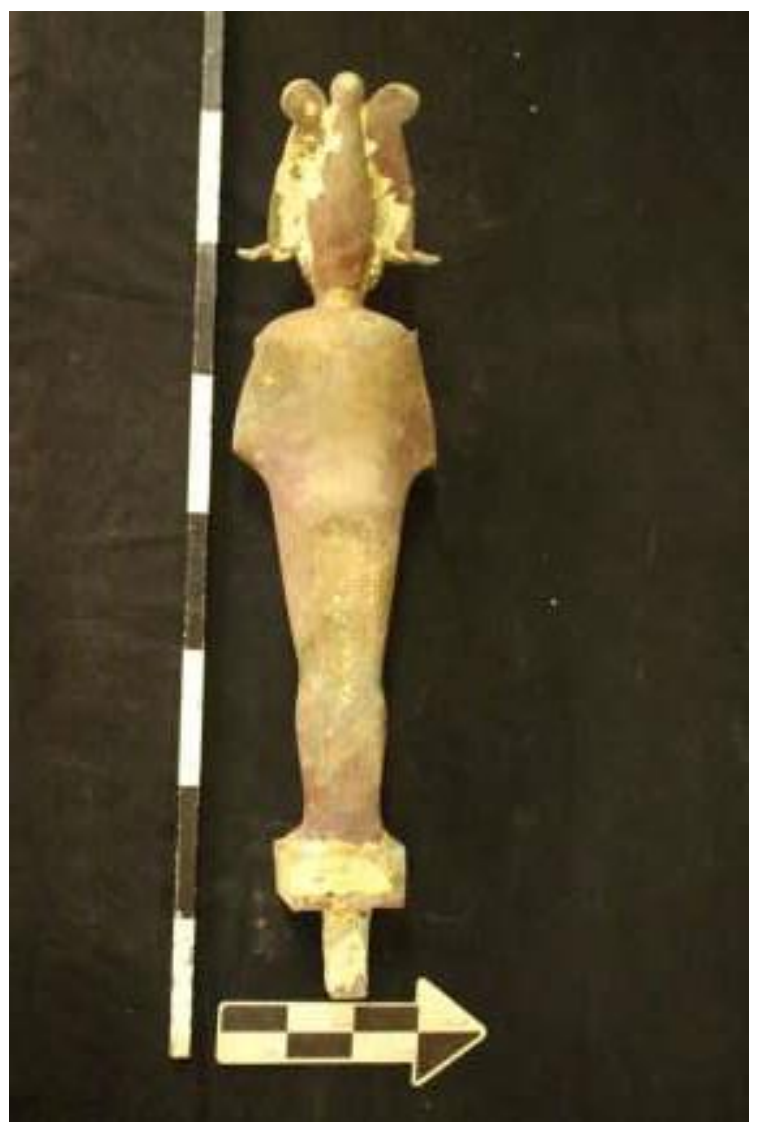

[FIGURE 15/C]

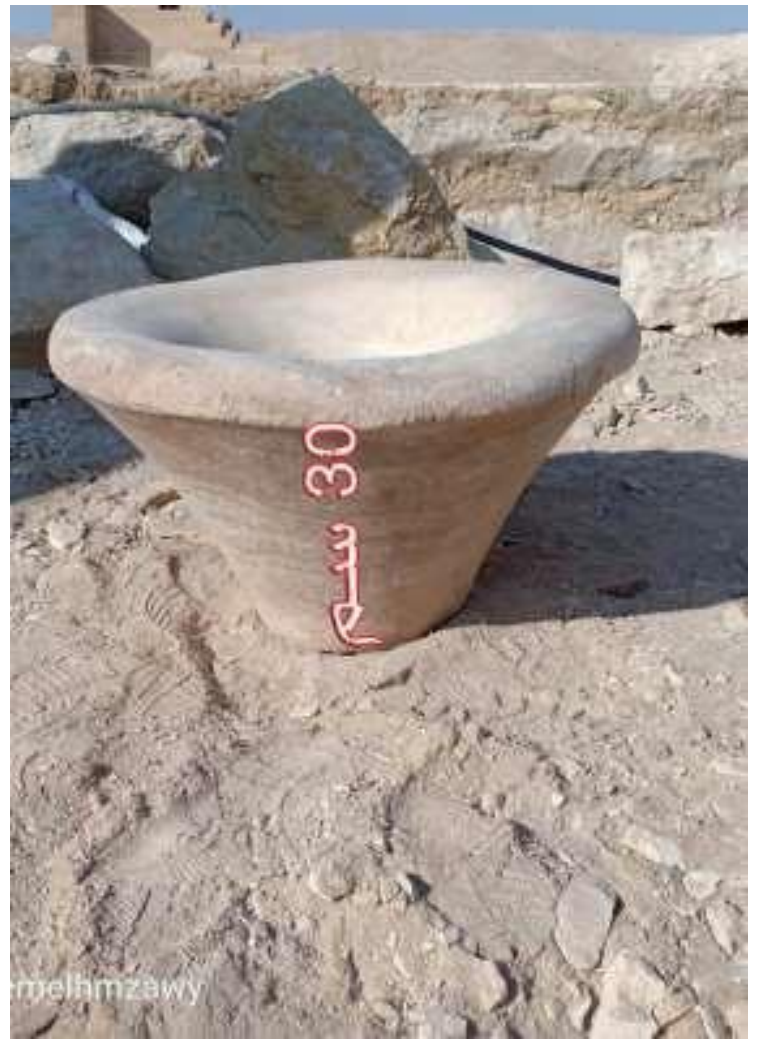

[FIGURE 15/D] 


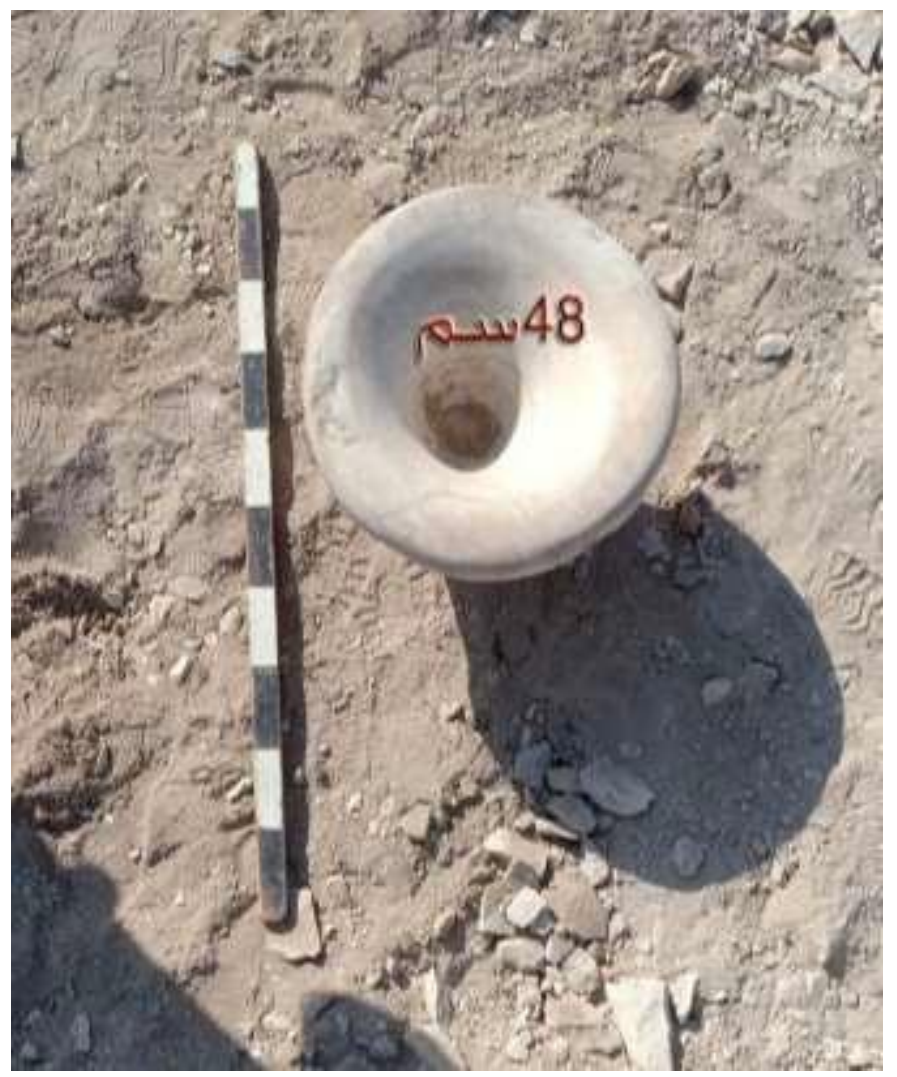

[FIGURE 15/E]

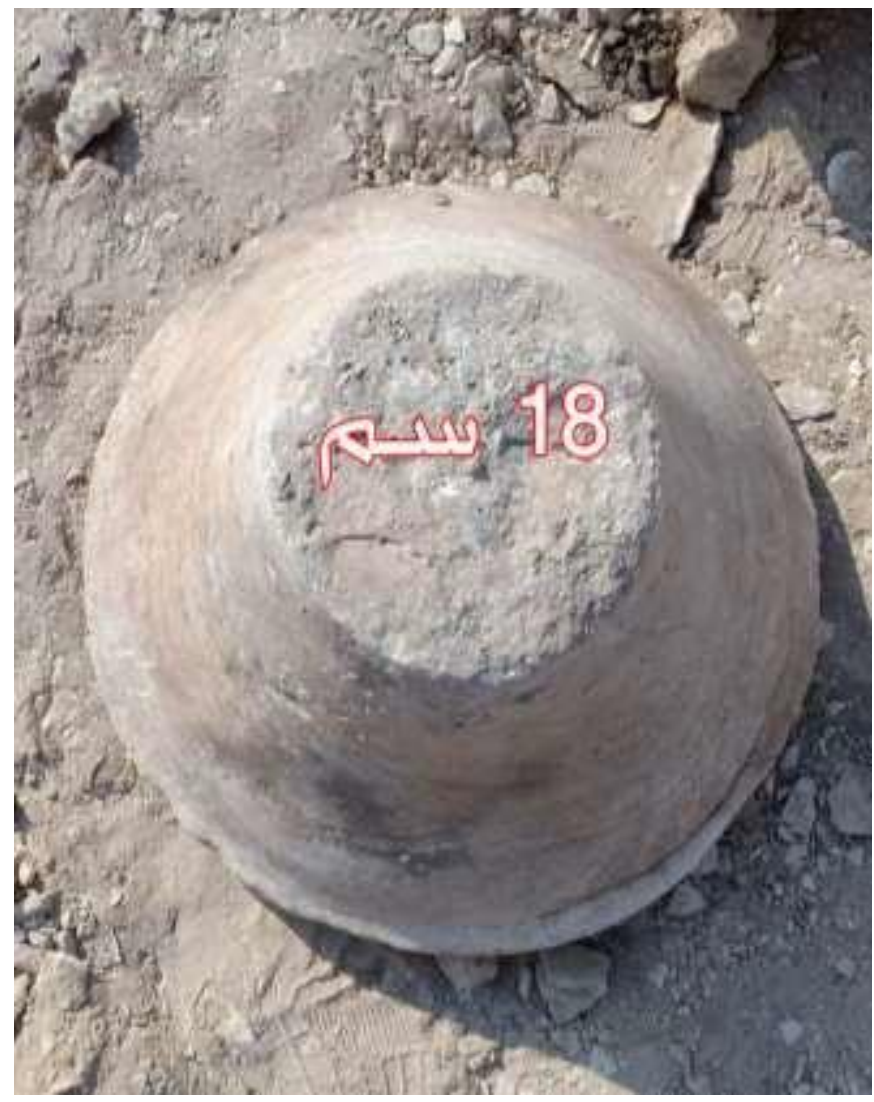

[FIGURE 15/F] 


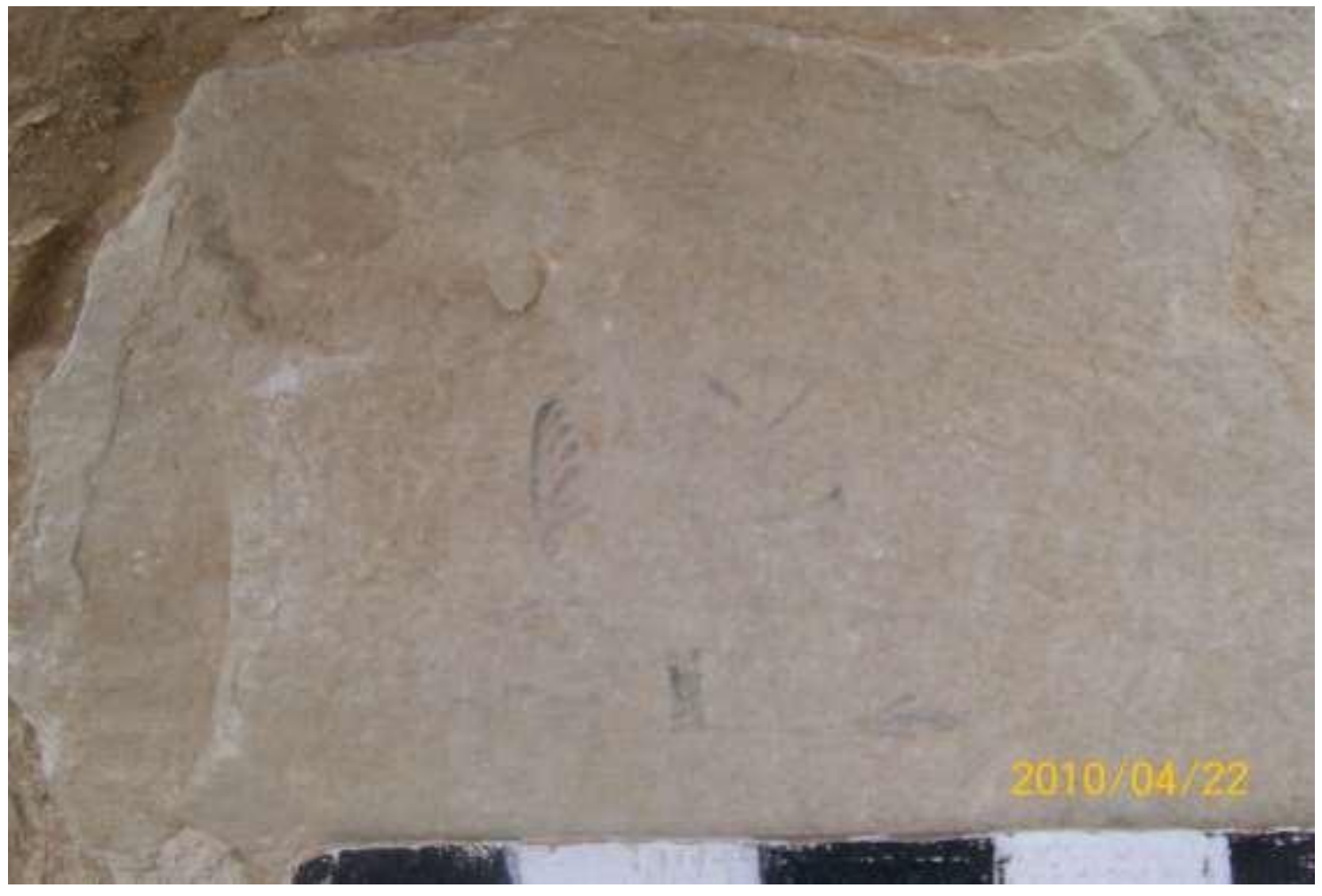

[FIGURE 16]: Graffiti @ Credit by HAWASS 2010.

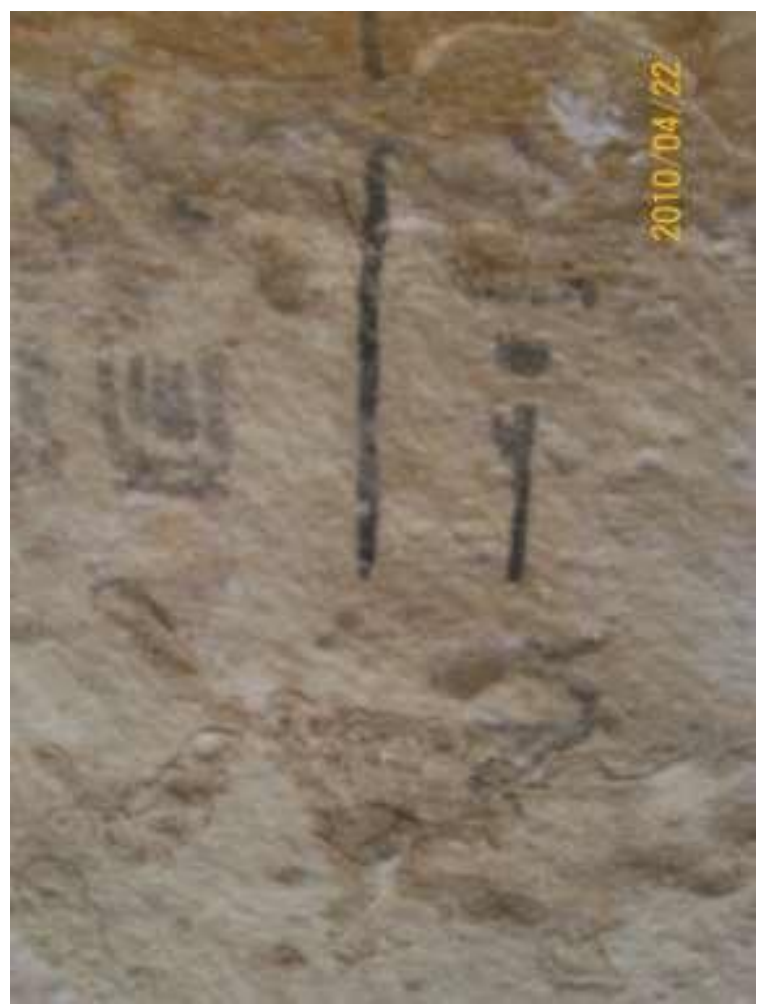

[FIGURE 17]: Graffiti. @ credit by HAWASS 2010. 


\section{Festschrift of Professor Ali Radwan [1941-2020]}

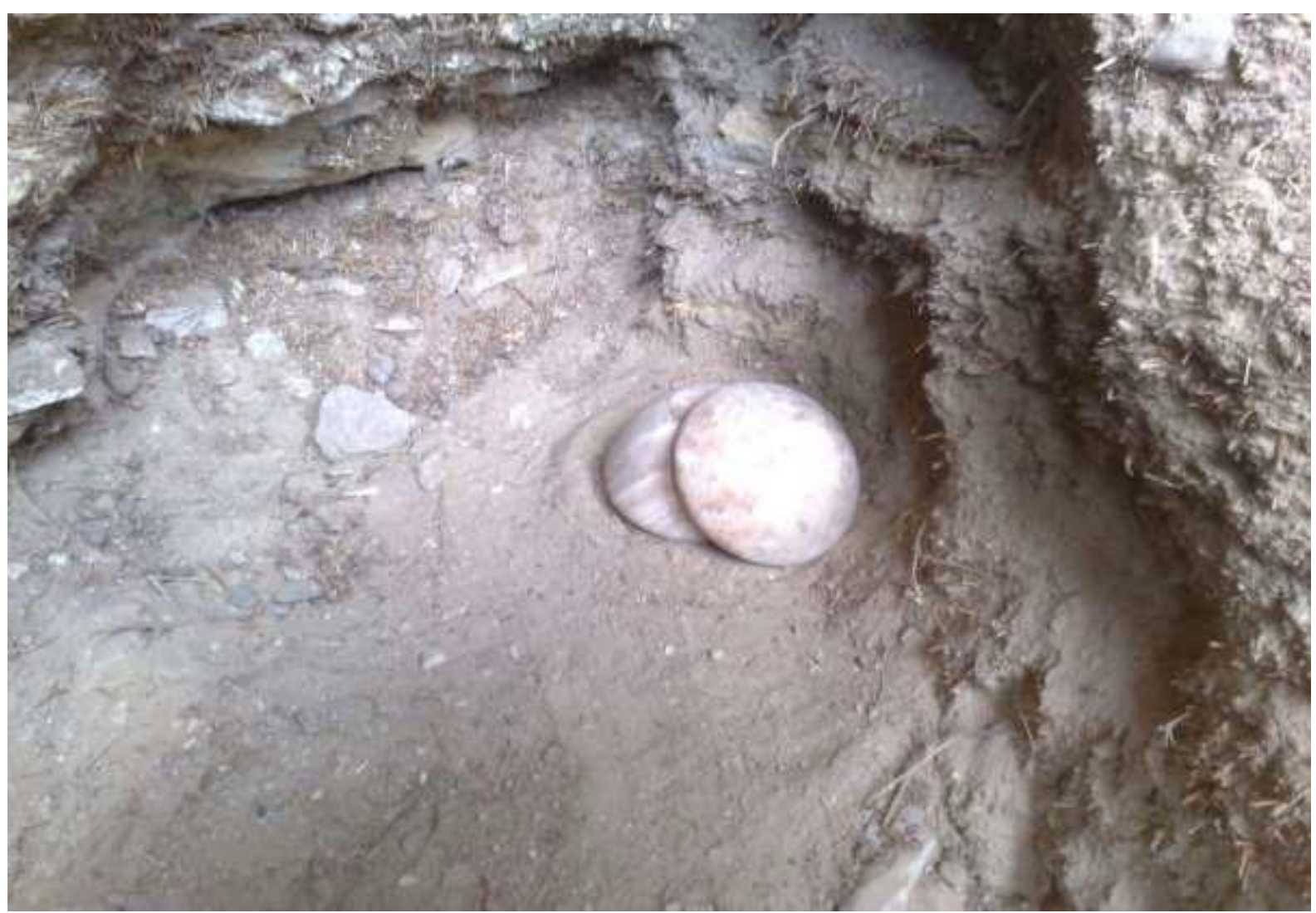

[FIGURE 18]: Two Alabaster vessels $@$ credit by HAWASS 2018. 


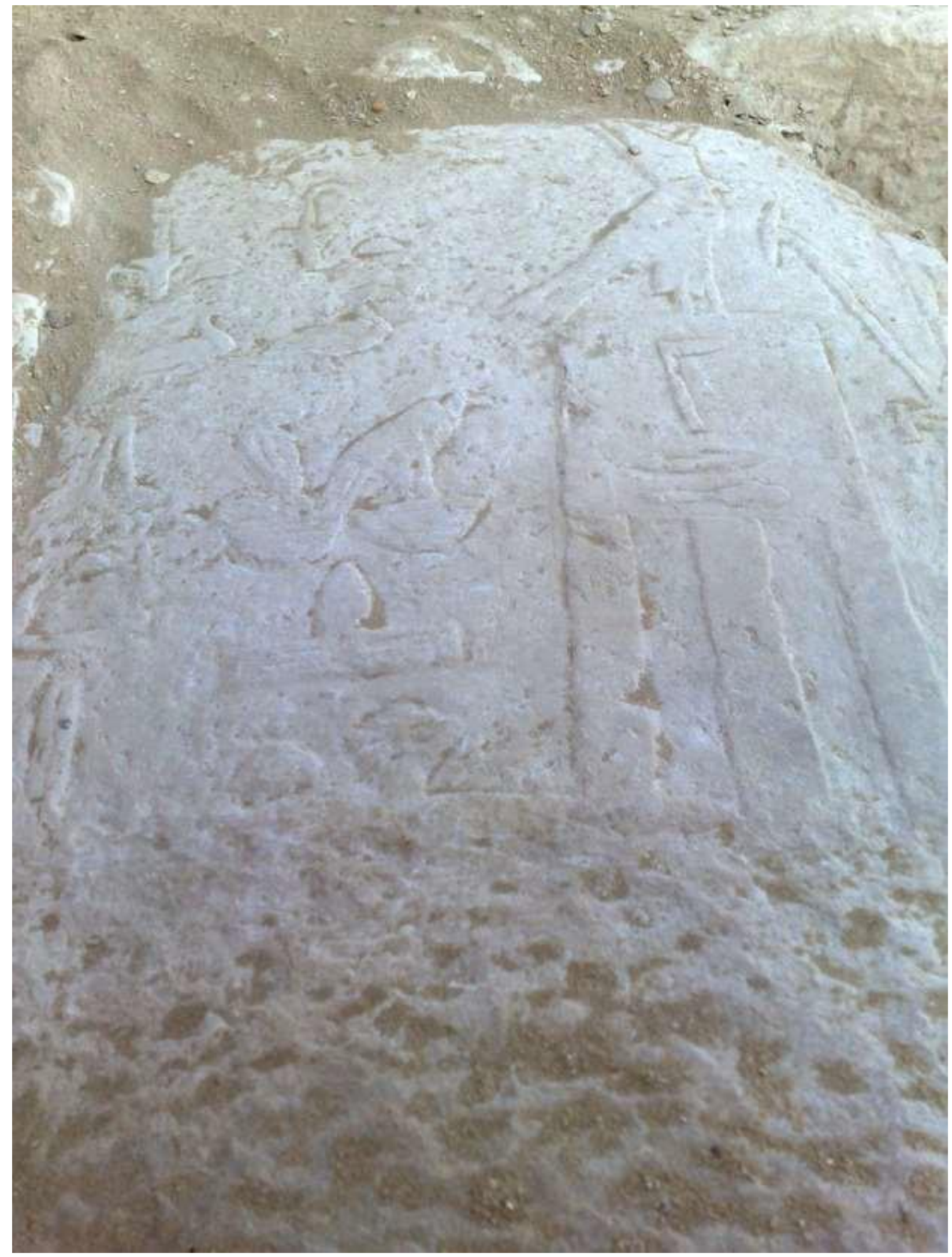

[FIGURE 19]: Boundary stela on it names and titles of Int-kes and Hetep 2r Nbty. (c) credit by HAWASS 2018. 


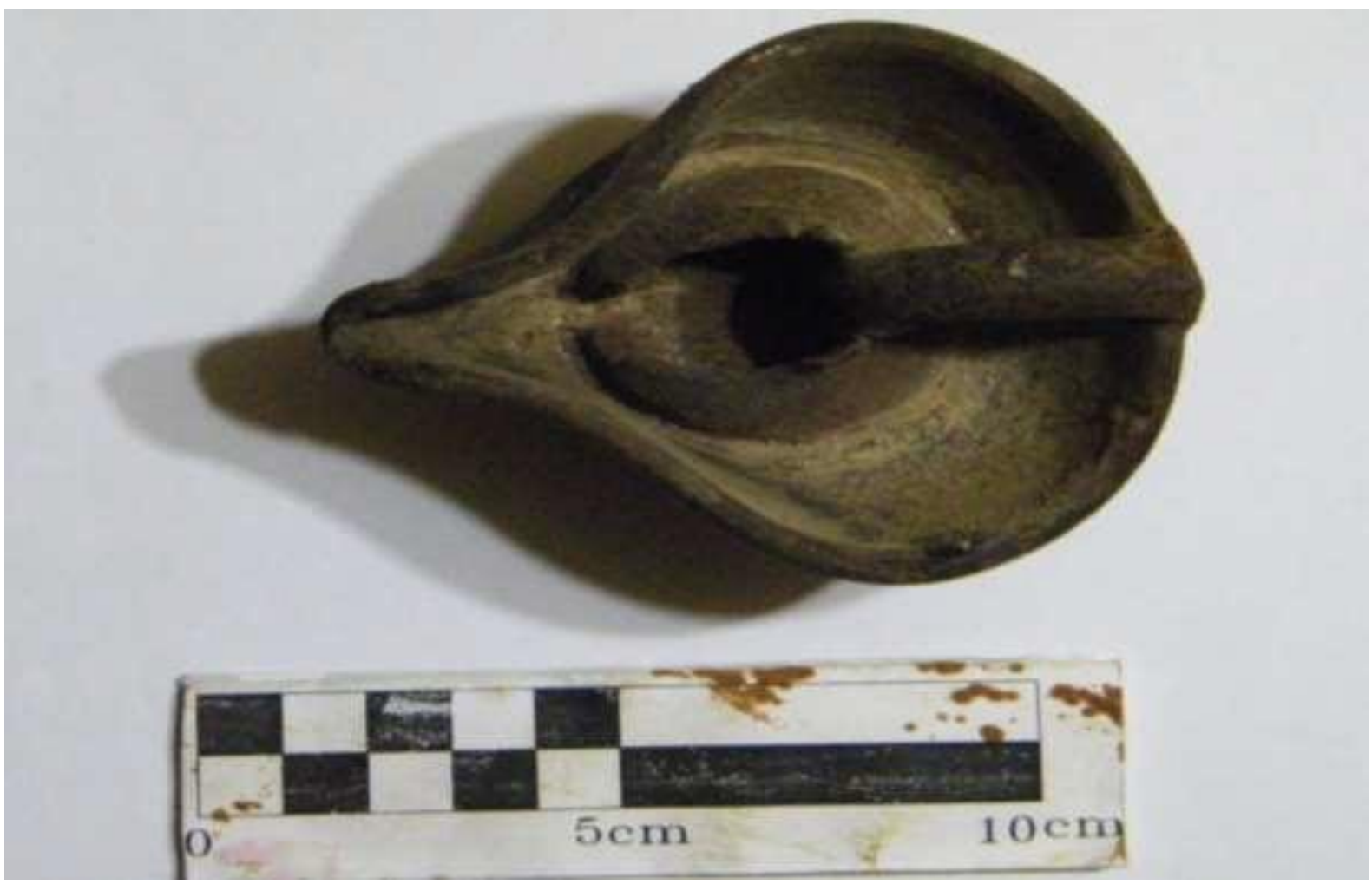

[FIGURE 20/A]: Pottery vessels $@$ credit by HAWASs 2018.

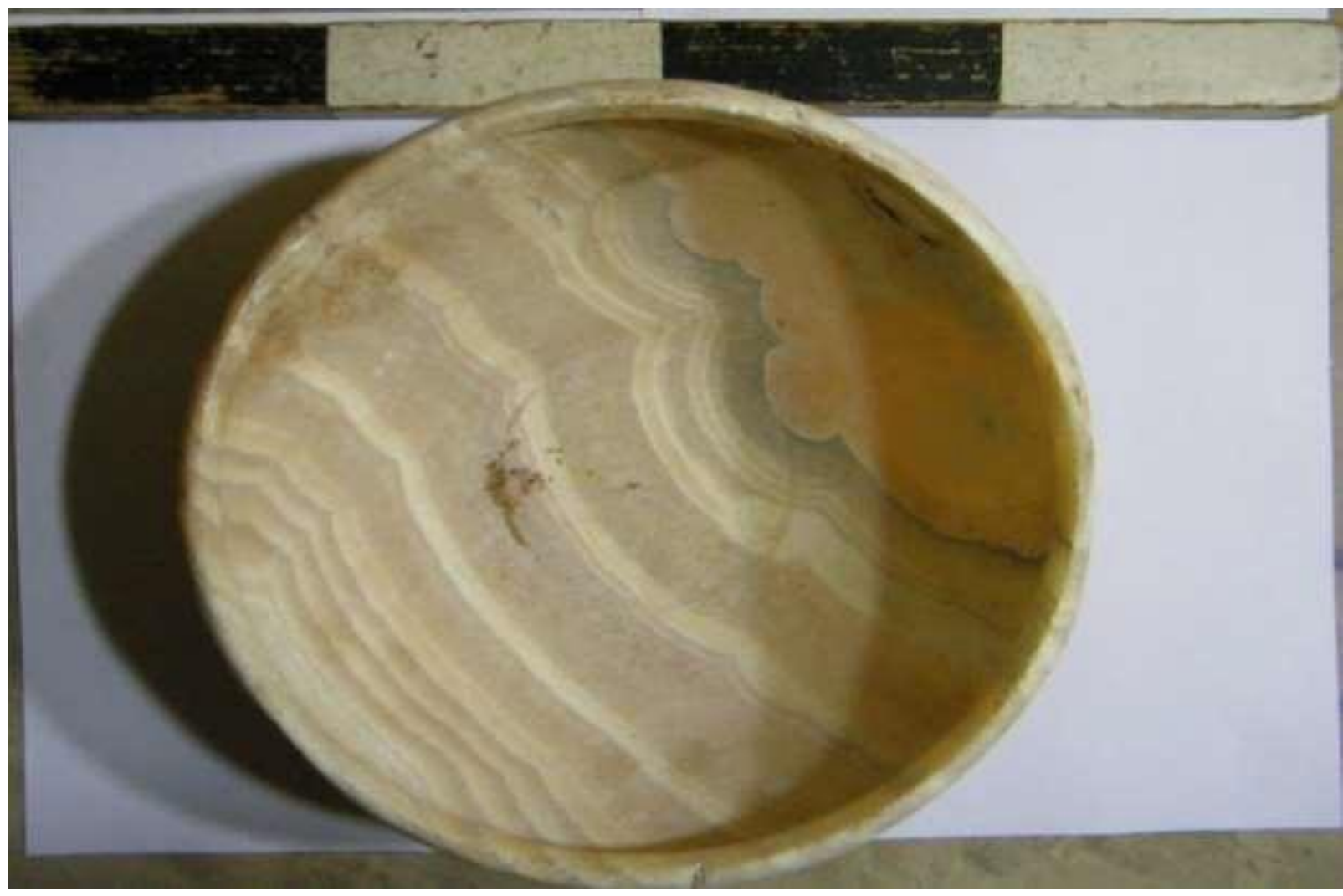

[FIGURE 20/B] 


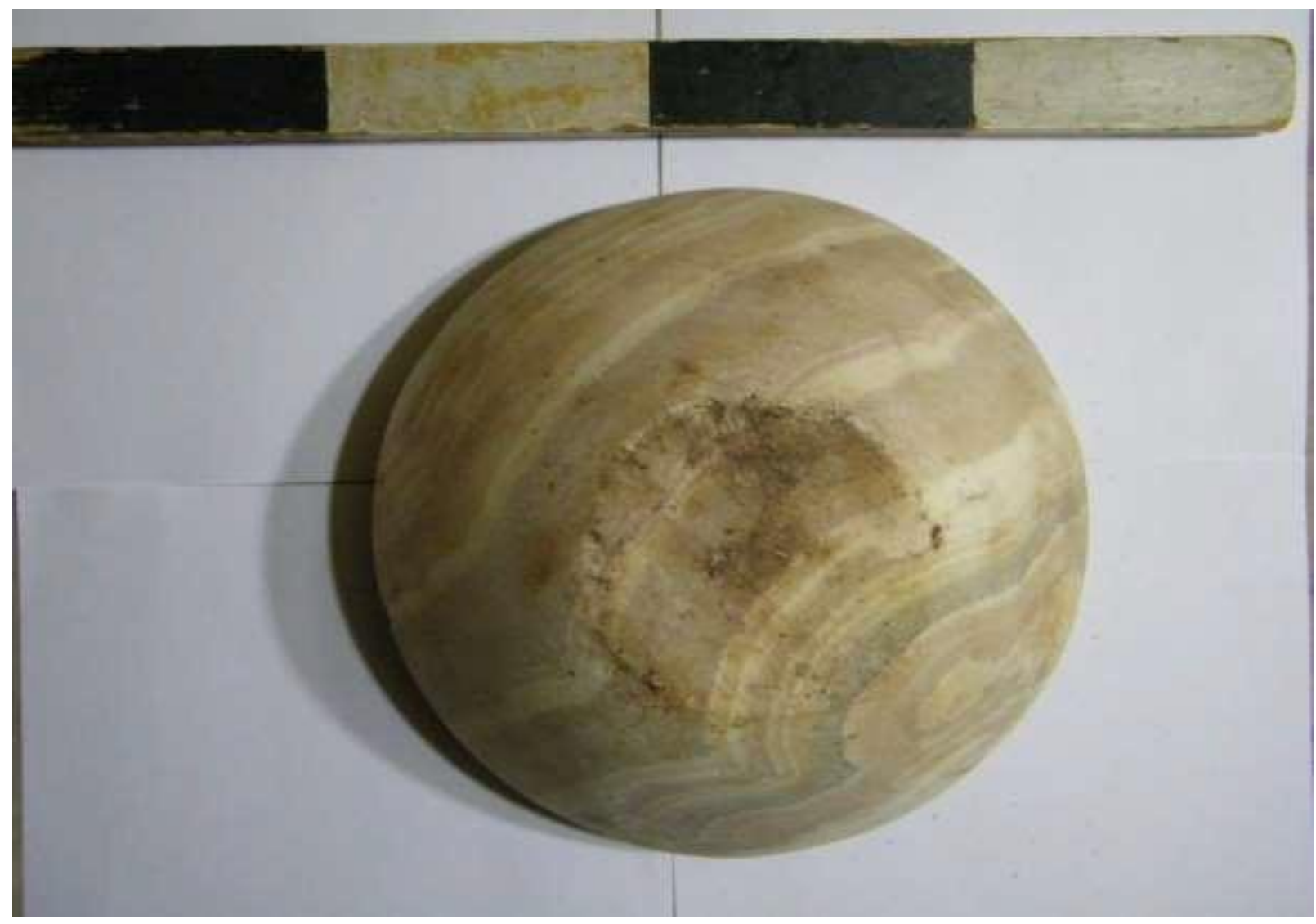

[FIGURE 20/C]

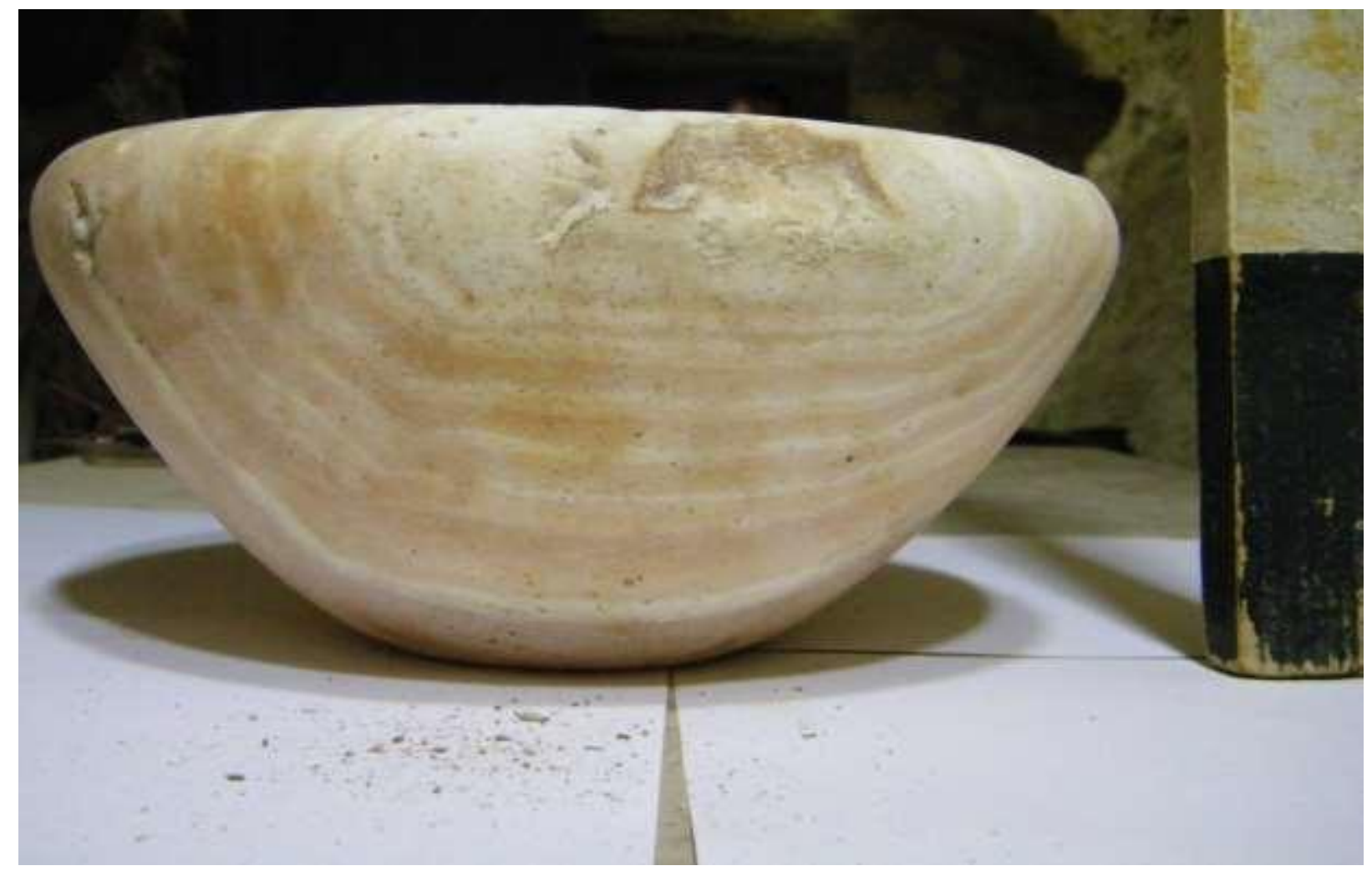

[FIGURE 20/D] 


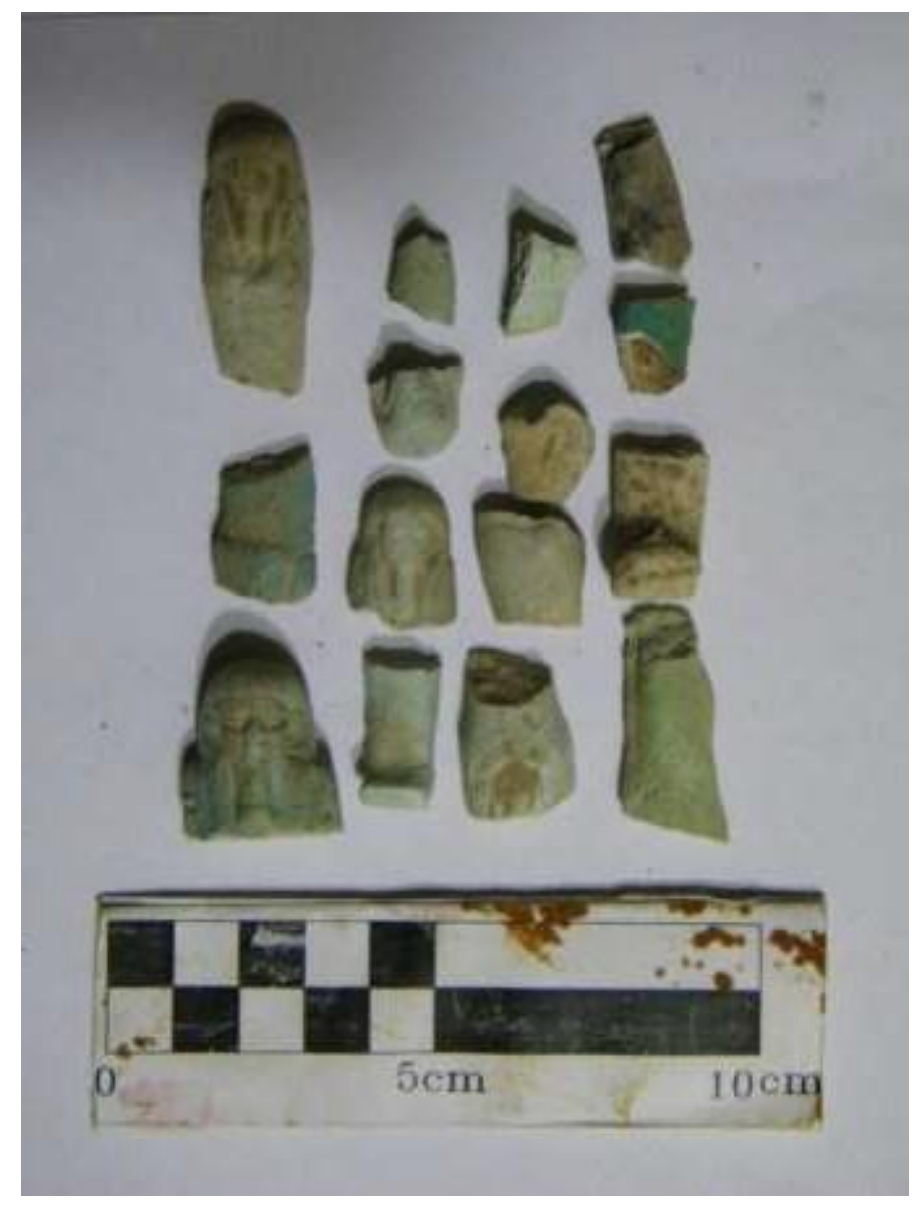

[FIGURE 20 / E]

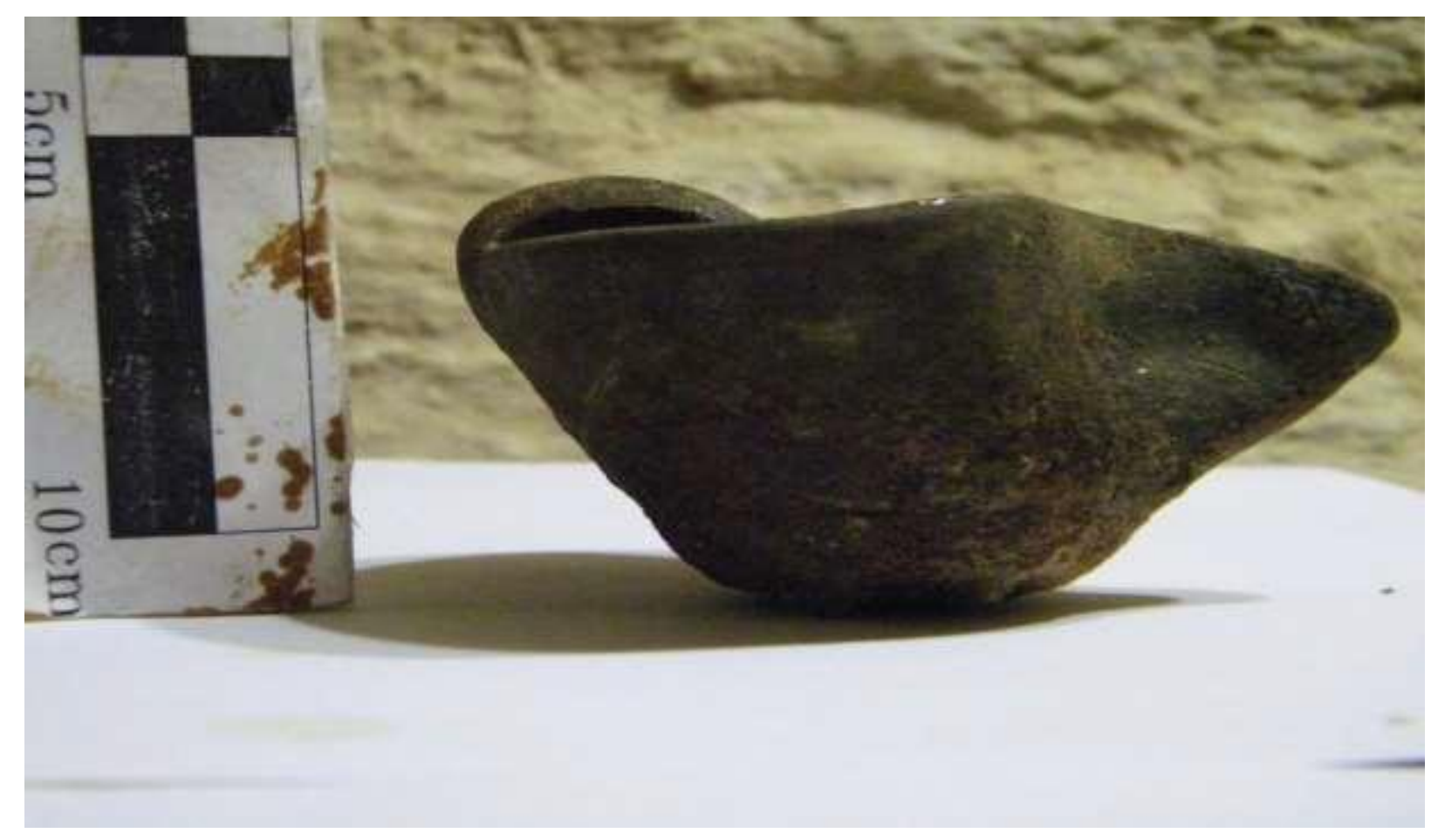

[FIGURE 20/F] 